
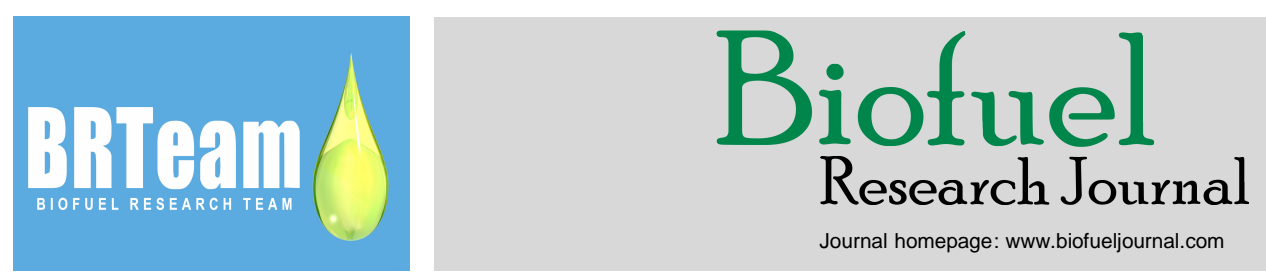

Journal homepage: www.biofueljournal.com

Review Paper

\title{
Green biodiesel production: a review on feedstock, catalyst, monolithic reactor, and supercritical fluid technology
}

\author{
Rizo Edwin Gumba ${ }^{1}$, Suryani Saallah ${ }^{1,2}$, Mailin Misson ${ }^{1}$, Clarence M. Ongkudon ${ }^{1,3, *}$, Ann Anton ${ }^{1,4}$ \\ ${ }^{1}$ Biotechnology Research Institute, Universiti Malaysia Sabah, Kota Kinabalu, Sabah, 88400, Malaysia. \\ ${ }^{2}$ Graduate School of Bio-Applications and Systems Engineering, Tokyo University of Agriculture and Technology, 2-24-16 Nakacho, Koganei, Tokyo 184- \\ 8588, Japan. \\ ${ }^{3}$ Energy Research Unit, Universiti Malaysia Sabah, Kota Kinabalu, Sabah, 88400, Malaysia. \\ ${ }^{4}$ Borneo Marine Research Institute, Universiti Malaysia Sabah, Kota Kinabalu, Sabah, 88400, Malaysia.
}

\section{HIGHLIGHTS}

$>$ Supercritical carbon dioxide $\left(\mathrm{SC}-\mathrm{CO}_{2}\right)$ for continuous biodiesel production has been reviewed. $>$ The potential of $\mathrm{SC}-\mathrm{CO}_{2}$ system to be applied in enzymatic reactors has been discussed. $>$ Monoliths as support matrices for enzyme immobilization have been reviewed.

\section{ARTICLE INFO}

\section{Article history:}

Received 30 October 2015

Received in revised form 5 July 2016

Accepted 11July 2016

Available online 1 September 2016

\section{Keywords:}

Algae biodiesel

Lipase immobilization

Monolithic bioreactor

Organic monolith

Inorganic monolith

Super critical carbon dioxide

\section{GRAPHICAL ABSTRACT}

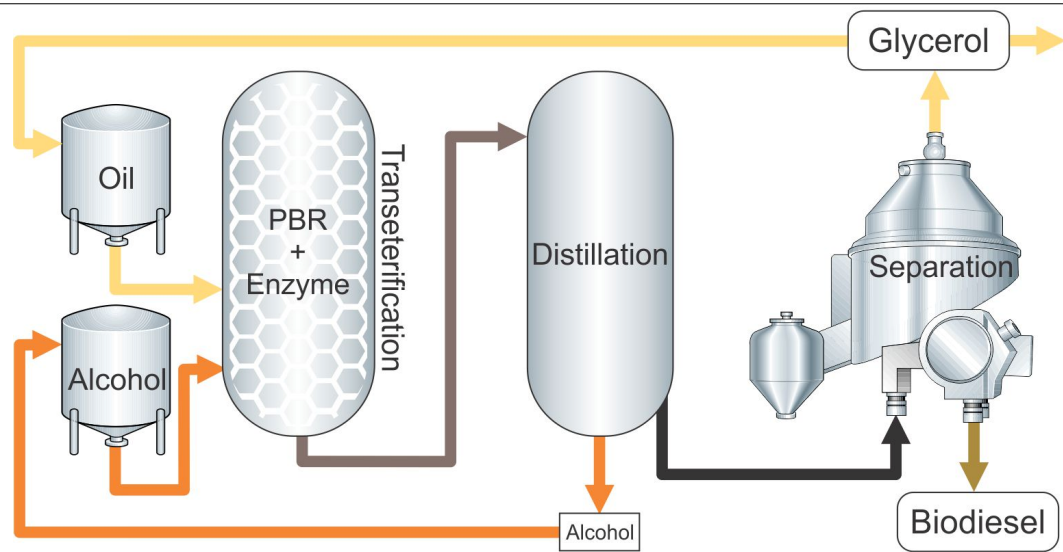

(C) 2016 BRTeam. All rights reserved.

* Corresponding author at: Tel.: +60 165091369

E-mail address: clarence@ums.edu.my

Please cite this article as: Gumba R.E., Saallah S., Misson M., Ongkudon C.M., Anton A. Green biodiesel production: a review on feedstock, catalyst, monolithic reactor and supercritical fluid technology. Biofuel Research Journal 11 (2016) 431-447. DOI: 10.18331/BRJ2016.3.3.3 


\begin{tabular}{|c|c|}
\hline \multicolumn{2}{|l|}{ Abbreviations } \\
\hline APPI & Atmospheric pressure photoionization \\
\hline C. antarctica & Candida antarctica \\
\hline CALB & C. antarctica lipase B \\
\hline $\mathrm{CaO}$ & Calcium oxide \\
\hline CCFS & Closed cross flow structures \\
\hline CLEA & Cross linking enzyme aggregate \\
\hline CRL & C. rugosa lipase \\
\hline EPA & Environmental Protection Agency \\
\hline FAME & Fatty acid methyl ester \\
\hline FFA & Free fatty acid \\
\hline J. curcas & Jatropha curcas \\
\hline $\mathrm{KOH}$ & Potassium hydroxide \\
\hline M-SILPs & Monolith-supported IL phases \\
\hline MPPM & Microporous polymeric matrix \\
\hline $\mathrm{NaOH}$ & Sodium hydroxide \\
\hline NREL & National Renewable Energy Laboratory \\
\hline OCFS & Open cross flow structures \\
\hline PBR & Packed bed reactor \\
\hline PEDS & Polyethoxydisiloxane \\
\hline PEG & Polyethylene glycol \\
\hline polyHIPE & poly-High internal phase emulsion \\
\hline ROL & Rhizopus oryzae lipase \\
\hline RSM & Response surface methodology \\
\hline RVO & Renewable Volume Obligation \\
\hline $\mathrm{SC}-\mathrm{CO}_{2}$ & Supercritical carbon dioxide \\
\hline $\mathrm{SCF}$ & Supercritical fluid \\
\hline STR & Stirred tank reactor \\
\hline T. lanuginosus & Thermomyces lanuginosus \\
\hline TEOS & Tetraethoxysilane \\
\hline TMOS & Tetramethoxysilane \\
\hline $\mathrm{Zr}$ & Zirconia \\
\hline
\end{tabular}

\section{Introduction}

Fossil fuel usage has become a major concern in the last decade due to the diminishing oil reserve and environmental effects associated with it. The world's oil production capacity is expected to decline within ten decades (Crookes, 2006). Alternative energy has been extensively researched to mitigate this problem focusing on its renewability, economic aspects, and environmental impacts. Biodiesel is one of the prominent candidates which have attracted numerous researchers from all over the world. One of the predominant advantages of biodiesel is that it can be used in existing engines, vehicles, and infrastructure with practically no changes (Du et al., 2008). The biodiesel properties are similar to those of petrodiesel fuel (Ranganathan et al., 2008). However, engines fueled with biodiesel emit significantly fewer particulates, hydrocarbons, and less carbon monoxides than those engines operating on petrodiesel thus reducing the greenhouse gas effect (Sheehan et al., 2000; Yee et al., 2009). Biodiesel is much safer than petrodiesel with a flash point of over $266{ }^{\circ} \mathrm{F}$ compared to about $126{ }^{\circ} \mathrm{F}$ for regular No. 2 diesel (ASTM standard D6751). They were 105 biodiesel production plants in operation as of early 2007 with a total production capacity of 864 million gallons and additional 1.7 billion gallons coming from plants under construction according to U.S. National Diesel Board. In 2013, The U.S. Environmental Protection Agency (EPA) set the Renewable Volume Obligation (RVO), in an annual rule making under a congressional mandate that called for the country to use 36 billion gallons of renewable fuels in transportation by 2022 (Schnepf and Yacobucci, 2010).

The quality of biodiesel is primarily determined by its fatty acid composition hence varies among different biodiesel feedstocks (Knothe, 2008; Ramos et al., 2009). It was reported by the U.S. Department of Energy in early 2014 that the price of biodiesel (B99-100) was approximately $\$ 4.28 /$ gal compared to petrodiesel with only $\$ 3.89 /$ gal (U.S. Department of Energy, 2014). The high price of biodiesel is directly associated with the cost of biodiesel feedstock. It is estimated that the raw material alone contributes to $75-90 \%$ of the total biodiesel production cost (Parawira, 2009). Since the production cost is directly proportional to the cost of raw material, a quest to select the best biodiesel feedstock is increasingly becoming a topic of interest in the development of an economically viable biodiesel production platform. Enzymatic transesterification of lipids using lipases is considered as highly effective since the glycerol can be recovered easily and economically (Vicente et al., 1998; Fukuda et al., 2001; Jegannathan et al., 2008). However, the major setback for its commercial application in biodiesel production is the high-price of lipase. In order to solve this problem, lipase can be immobilized onto a solid support to allow repeated use in batch or continuous reaction processes (Balcão et al., 1996; Hama et al., 2007). The choice of a support matrice for enzyme immobilization is based on several factors, namely the loading capacity, ease of regeneration, kinetic stability, functional groups availability, microbial resistance, mechanical strength. and cost (Urban et al., 2012). There are various support materials available such as porous beads (Gao et al., 2006) and monoliths (Orçaire et al., 2006; Eeltink et al., 2007).

The advancement of technology in biodiesel production has led to the development of an enzymatic monolithic reactor. In comparison with packed bed reactor (PBR) and stirred tank reactor (STR), integrating enzymes on a monolithic reactor facilitates better mass transfer and lower bed pressure drop, besides permitting higher substrate flow rate thus enhancing biodiesel productivity (Santos and Costa, 2009). Chemical catalysts, both homogenous and heterogenous have been widely used to catalyze the conversion of oil into biodiesel. However, both types of chemical catalysts are often associated with the corrosion effect and formation of soap in the reaction medium containing high free fatty acid (FFA) or water (Canakci and Gerpen, 1999), leading to the development of non-catalytic supercritical transesterification. This catalyst-free reaction is much simpler and environmentally-friendly due to the absence of toxic chemicals.

Supercritical biodiesel production, employed at temperatures and pressures above the critical value of fluid provides improved mass transfer rate while promoting esterification and transesterification at high rates (Kondoh and Fukuda, 2008). Biodiesel synthesis in supercritical carbon dioxide $\left(\mathrm{SC}-\mathrm{CO}_{2}\right)$ thus provides an alternative to the expensive supercritical methanol-based method. $\mathrm{SC}-\mathrm{CO}_{2}$ can be operated at mild temperatures and pressures. The integration of enzymatic monolithic reactor with supercritical carbon dioxide is now becoming a cutting-edge research in the field of biofuel. An extensive review highlighting this technology in biodiesel production is also less published.

This article aims to review the potential of integrating enzymatic reactors with $\mathrm{SC}-\mathrm{CO}_{2}$ for biodiesel production using microalgae as the feedstock. The different generations of biodiesel feedstock are firstly discussed. The catalysts used for the transesterification of oil into fatty acid methyl ester (FAME) are highlighted in the next section followed by strategies for lipase immobilization and detailed description of $\mathrm{SC}-\mathrm{CO}_{2}$ enzymatic-based monolith reactor. Previous published works employing this technology for biodiesel production are also highlighted. This review also provides perspectives and challenges associated with the commercialization of this technology.

\section{1. $1^{\text {st }}$ and $2^{\text {nd }}$ generation biodiesel feedstocks}

Several generations of feedstocks have been used for biodiesel production as shown in Figure 1. $1^{\text {st }}$ generation biodiesel feedstocks are mainly produced from plants such as soybean, jatropha, palm oil, and canola oil (Ong et al., 2011) or animal fats (Ma et al., 1998). The economic viability and sustainability of the $1^{\text {st }}$ generation feedstock however has come under scrutiny. Environmentalists claim that the expansion of oil crop plantations for large scale biodiesel production has resulted in deforestation in countries such as Malaysia, Indonesia, Argentina, and Brazil (Gao et al., 2011). The situation is further deteriorated by the competition for arable land for food and fiber plantation, high consumption of water and fertilizer, and poor agricultural practices. Thus, the first generation feedstock is claimed to be inefficient since it affects the food security and global food markets (Noraini et al., 2014). In order to overcome this problem, $2^{\text {nd }}$ generation biodiesel produced from non-edible by-products and wastes has been proposed. However, the biggest challenge of the $2^{\text {nd }}$ generation biodiesel production is the availability of cropland enough to produce these by-products for biodiesel production in a commercial scale. Hence, there is a need to 
explore alternative feedstocks for biodiesel production that have less impact on the food industry (Cheng and Timilsina, 2011).

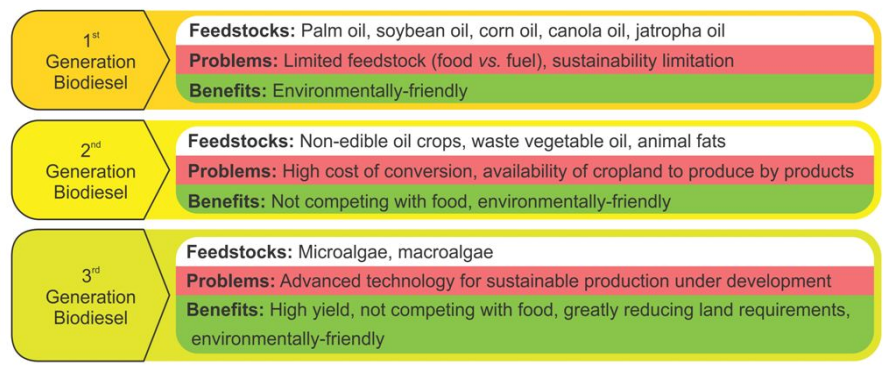

Fig.1. Development of biodiesel feedstocks.

\subsection{Algae as a biodiesel feedstock}

In the past decade, algae have emerged as a promising feedstock for biodiesel production. Numerous studies have indicated algae as a superior feedstock for biodiesel production compared to $1^{\text {st }}$ and $2^{\text {nd }}$ generation biodiesel feedstocks due to its high environmental index and high fuel efficiency (Brennan and Owende, 2010). The cultivation of microalgae can be performed on non-arable lands thus avoiding the increase of farmlands required for oleaginous plants. Oil yield per-acre-per-year of microalgae is approximately 150 - 200 times higher than that of plants (Chisti, 2007). Microalgae also have high photon conversion efficiency (as evidenced by the increased biomass yields per hectare) and the ability to utilize salt and waste water streams, thus significantly reducing freshwater consumption (Chisti, 2007; Li et al., 2008; Schenk et al., 2008). Under suitable conditions, algae can double its biomass in $24 \mathrm{~h}$ and produce up to $50 \%$ lipid to dry biomass ratio (Chisti, 2007). Algae do not compete with other feedstocks for natural resources and further; they do not impact food prices as is the case, for instance, with corn-based biodiesel. It is estimated that algae can produce up to $15,000 \mathrm{gal} / \mathrm{acre} / \mathrm{y}$ compared to soybean oil (48 gal/acre/y), peanut oil (113 gal/acre/y), rapeseed oil (127 gal/acre/y), and palm oil (635 gal/acre/y) as reported by the U.S. National Renewable Energy Laboratory (NREL).

However, oil extracted from vegetables (plant or microalgae) introduces new problems if it is to be directly used in existing engines. Problems such as coking and trumpet formation on the injectors, carbon deposits, oil ring sticking, thickening, and gelling of the lubricating oils have been encountered due to their high viscosity and tendency to polymerize during combustion (Ma and Hanna, 1999; Altın et al., 2001; Rakopoulos et al., 2006). Several methods have been introduced to solve these problems including microemulsions, pyrolysis, and transesterification with the sole purpose of reducing the viscosity of oil extracted from plants (Marchetti e al., 2007). Among all these alternatives, transesterification is likely the best choice as the process is simple, and the physical characteristics of the FAME (biodiesel) are very close to those of diesel fuel (Demirbas, 2009). Transesterification is the catalytic process of exchanging the alkoxy group of an ester by an alcohol (acyl acceptor) that converts the triglyceride in oils to FAME and glycerol. Chemical (acids or bases) and biological (enzymes) agents can be used effectively as catalysts (Noureddini and Zhu, 1997; Xu et al., 2003; Shah et al., 2004; Čerče et al., 2005; Leung et al., 2010).

\section{Catalysts for lipid transesterification}

As mentioned earlier, biodiesel is produced via transesterification reaction in the presence of a catalyst to convert raw lipid (triacylglycerol/FFAs) into renewable, environmentally friendly and biodegradable diesel known as mono-alkyl esters of long fatty acid (Baskar and Aiswarya, 2016). Besides feedstock, the type of catalyst is also important in biodiesel production. Various types of catalyst have been employed in transesterification process including chemical and biological catalysts, in homogeneous and heterogeneous forms. The type of catalyst and reaction condition used for lipid transesterification directly affects the yield and quality of the biodiesel produced (Table 1 ).

\subsection{Chemical catalyst}

During the conversion of triglyceride into FAME, the anion of alcohol attacks the carbonyl group of triglyceride molecules forming an intermediate tetrahedral, which rearranges to form diglyceride and fatty acid ester. The mechanism is repeated stepwise to liberate diglyceride, monoglyceride, and glycerol while the catalyst is later recovered through a proton transfer (Aransiola et al., 2014). The process is a reversible reaction although the reaction equilibrium favors the production of fatty acid and glycerol (Ma and Hanna, 1999).

\subsubsection{Homogenous catalyst}

Most industrial-scale biodiesel productions rely on homogenous catalysts that usually make use of either acid or base catalyst in liquid

Table 1.

Reaction conditions and performance of biodiesel production using various types of catalyst (Lam et al., 2010; Leung et al., 2010; Math et al., 2010; Taher et al., 2011a; Sani et al., 2013).

\begin{tabular}{|c|c|c|c|c|}
\hline Parameter & Homogenous catalyst & Heterogenous catalyst & Supercritical alcohol & Enzymatic catalyst \\
\hline Reaction temperature & $40-75^{\circ} \mathrm{C}$ (base catalyst), $50-100^{\circ} \mathrm{C}$ (acid catalyst) & $60-65^{\circ} \mathrm{C}$ (base catalyst), $30-460^{\circ} \mathrm{C}$ (acid catalyst) & $230-350{ }^{\circ} \mathrm{C}$ & $35-60{ }^{\circ} \mathrm{C}$ \\
\hline Reaction pressure & Atmospheric pressure & $0.05-20 \mathrm{Mpa}$ & $19-35 \mathrm{Mpa}$ & $\mathrm{N} / \mathrm{A}^{*}$ \\
\hline Molar ratio Alcohol : oil & $3: 1-9: 1$ (base catalyst), 30:1 - 50:1 (acid catalyst) & $6: 1-18: 1$ (base catalyst), 6:1 - 70:1 (acid catalyst) & $40: 1-45: 1$ & $3: 1-18: 1$ \\
\hline $\begin{array}{l}\text { Reaction time for complete } \\
\text { transesterification }\end{array}$ & $1-4 \mathrm{~h}$ (base catalyst), more than $4 \mathrm{~h}$ (acid catalyst) & $0.5-2 \mathrm{~h}$ (base catalyst), $3-20 \mathrm{~h}$ (acid catalyst) & $3 \mathrm{~min}-1 \mathrm{~h}$ & More than $24 \mathrm{~h}$ \\
\hline Glycerol recovery & Difficult (base catalyst), moderate (acid catalyst) & Moderate (base catalyst), Easy (acid catalyst) & Easy & Easy \\
\hline Product purification & Difficult (base catalyst), Moderate (acid catalyst) & Easy (base catalyst), Easy (acid catalyst) & Easy & Easy \\
\hline Catalyst cost & Cheap & Moderate & Expensive & Expensive \\
\hline Effect of water & $\begin{array}{l}\text { Inhibit reaction (base catalyst), Tolerant to low water } \\
\text { content (acid catalyst) }\end{array}$ & $\begin{array}{l}\text { Inhibit reaction (base catalyst), Tolerant to low water } \\
\text { content (acid catalyst) }\end{array}$ & Increase reaction rate & $\begin{array}{l}\text { Negative effect if too } \\
\text { much }\end{array}$ \\
\hline Effect of FFA & $\begin{array}{l}\text { Soap formation (base catalyst), No influence (acid } \\
\text { catalyst) }\end{array}$ & $\begin{array}{l}\text { Soap formation (base catalyst), No influence (acid } \\
\text { catalyst) }\end{array}$ & No influence & No influence \\
\hline Reusability & No & Yes & Yes & Yes \\
\hline
\end{tabular}

*N/A: not available 
form. In the alkaline catalyst process, strong base such as potassium hydroxide $(\mathrm{KOH})$ or sodium hydroxide $(\mathrm{NaOH})$ at a concentration range of $0.5-1$ wt.\% is used as a catalyst along with short-chain alcohol such as methanol or ethanol at a temperature range between $45-80{ }^{\circ} \mathrm{C}$. $\mathrm{NaOH}$ is the popular choice for industrial application because of the low price and high biodiesel yield (Kim et al., 2004). This process is the most efficient and least corrosive of all the processes (Ranganathan et al., 2008). Initially, reaction between catalyst and alcohol takes place forming alcoxy, the alcoxy is then reacted with any triacyleglycerols forming biodiesel and glycerol. Product recovery is simple as glycerol being denser than biodiesel settles down at the bottom forming separated liquid phase allowing biodiesel to be decanted easily. Although the alkaline catalyst process produces biodiesel fuel of high quality, the formation of soap is likely to take place when high FFA or water content is present in the oil, which is the usual case for low cost biodiesel feedstock such as non-edible oil, used oil or animal fat, making this process unfavorable. Acid can be used to catalyze the conversion of lipid into biodiesel. Sulfuric acid or hydrochloric acid is commonly employed as a catalyst at concentrations in the range of $0.5-1 \mathrm{wt} . \%$ with temperatures of 60 $100{ }^{\circ} \mathrm{C}$. Although the biodiesel yield is high, acid-catalyzed process is often corrosive in nature causing damage to equipments and the reaction rate is low (Canakci and Gerpen, 1999). Moreover, the major drawback of a homogenous catalyst is the need to operate it at a relatively high temperature besides the release of undesired by-products. The requirement for separation and purification of final product also renders this technique challenging and costly.

\subsubsection{Heterogeneous catalyst}

Heterogeneous catalyst offers an economic solution to homogenous catalyst as they can be easily recovered and reused for successive cycles with ease of product separation and purification (Endalew et al., 2011). Heterogeneous catalyst is less hazardous and creates less environmental problems. Comprehensive reviews highlighting the various heterogeneous catalysts and their preparation have been reported in the literature (Helwani et al., 2009; Chouhan and Sarma, 2011; Borges and Diaz, 2012). Conventional heterogeneous base catalysts are derived from alkaline earth metal oxides and its derivatives (e.g., $\mathrm{MgO}, \mathrm{CaO}, \mathrm{BaO}$ ). Meanwhile, acid catalysts are usually made from sulfate salts, zirconium oxide, titanium oxide, tin oxide, and heteropolyacid. The main advantage of heterogeneous base catalyst over acid catalyst is their ability to carry out transesterification at high reaction rates and lower reaction temperatures. Calcium oxide is among the popular choice of conventional heterogeneous base catalysts due to its long shelf-life, high basicity, moderate reaction conditions, and lower price in comparison with other heterogeneous base catalysts. (Zhu et al., 2006). Bai et al. (2009) reported that as high as $98 \%$ of FAME was obtained using $\mathrm{CaO}$ catalyst. Nevertheless, $\mathrm{CaO}$ has been reported causing leaching during transesterification, catalyst deterioration upon contact with air, and active site poisoning (Chouhan and Sarma, 2011). Moreover, the requirement for pretreatment of oil to overcome the problem of soap formation when high FFA content is present in the reaction has become a major hurdle for heterogeneous base catalyst in biodiesel processing.

Heterogeneous acid catalyst has the advantage when dealing with biodiesel feedstocks with high level of FFA contents. Besides being unsusceptible to high FFA contents, heterogeneous acid catalyst allows easy product separation and greater recyclability (Melero et al., 2009). Jitputti et al. (2006) reported over 90\% FAME yield using heterogeneous acid catalyst for biodiesel production. Zirconia ( $\mathrm{Zr}$ )-based acid catalyst is favorable due to the high number of Brönsted acid on its surface. However, in addition to longer reaction time and higher temperature requirement, $\mathrm{Zr}$ is a rare metal hence the catalyst fabrication is expensive. The constant efforts made in addressing the issues associated with heterogeneous base and acid catalysts have led to the development of advanced heterogeneous catalysts that offer simultaneous esterification and transesterification benefits.

Generally, the building block of modern heterogeneous catalysts is a spinel mix of two (non-noble) metals (Helwani et al., 2009) which determine the basic and acidic characteristics of the catalysts. These features allow users to fabricate catalysts with preferred functionalities by adding certain metals that favor the desired catalytic properties. Yan et al. (2009) reported the application of a modern heterogeneous catalyst for the conversion of unrefined waste cooking oil into biodiesel. A conversion efficiency of $96 \%$ was observed in a reaction performed at $200{ }^{\circ} \mathrm{C}$ for $3 \mathrm{~h}$ using zinc/lanthanum ratio of 3:1. The mixture of zinc and lanthanum was found to exhibit higher catalytic activities than pure metal oxides with higher tolerance against FFA and water content.

Kondamudi et al. (2011) employed quintinite-based heterogeneous catalyst for biodiesel synthesis from various waste vegetable oils. The reaction was carried out at a temperature of $70{ }^{\circ} \mathrm{C}$ for $2 \mathrm{~h}$ using $2: 1 \mathrm{Al} / \mathrm{Mg}$ ratio, giving a conversion efficiency of $\sim 98 \%$ and a reasonable catalytic stability after 5 runs. Other successful applications of modern heterogeneous catalysts have also been reported elsewhere (Soldi et al. 2009; Cannilla et al., 2010; Macario et al., 2010; Salinas et al., 2010; Wen et al., 2010). Despite the high conversion efficiency, such catalysts however, have several disadvantages including harsh reaction conditions, energy intensive process, difficulty in by-product removal, and feedstock pretreatment requirement.

\subsection{Supercritical fluid technology}

Although heterogeneous catalysts have been explored to overcome problems related to homogenous catalysts, the same inherent drawbacks are still found on both technologies, the requirement of pretreatment of FFA and separation of water and glycerol. If the mixture is left untreated, soap formation may occur and consequently the catalysts are deactivat Thus, non-catalytic supercritical transesterification of lipid has been proposed to overcome the above problem. As a result of the catalyst absence, product separation is much simpler and environmental friendly. Moreover, studies have shown that the presence of water in the reaction further promotes supercritical transesterification (Minami and Saka, 2006; Tan et al., 2010a; Niza et al., 2013). The principle of supercritical fluid (SCF) in biodiesel processing is where the transesterification reaction is carried out at temperatures and pressures above the critical value of the fluid. In this state, the fluid properties are the intermediate of its liquid and gas phases. SCFs have higher solvent properties than gases and better transport properties than liquids. Consequently, mass transfer rate is improved due to the relatively low viscosity, high diffusivity, and low surface tension (Kondoh and Fukuda, 2008). Under such conditions, the mixture of feedstock (triglyceride) and acyl acceptor (alcohol) becomes homogenous where esterification and transesterification can be carried out simultaneously at a high rate. Homogenous reaction in supercritical fluid can be explained by the increase in solubility of non-polar triglyceride as temperature and pressure increase, while lowering the dielectric constant of alcohol resulting in a hydrophobic nature of alcohol. As a result, nonpolar triglycerides dissolve easily forming a single phase of oil/alcohol/SCF mixture (Lee and Saka, 2010). As opposed to the previously mentioned catalyst reaction, supercritical transesterification is suitable for any types of biodiesel feedstocks especially low cost feedstocks containing a high level of FFA. Additionally, the reaction rate of supercritical transesterification is proven to be superior to catalystassisted reaction (Demirbas, 2005; Minami and Saka, 2006; Endalew et al., 2011).

\subsubsection{Supercritical alcohol}

The most studied SCF-based biodiesel production method deals with supercritical methanol and also known as the Saka method (Saka and Kusdiana, 2001). The supercritical methanol method has been proven to produce a high yield of biodiesel at a very fast reaction rate compared to other methods aforementioned. In this reaction, hydrogen bonding of methanol is significantly reduced allowing methanol to become a free monomer. It is suggested that, depending on pressure and temperature, methanol molecule can directly attack the carbonyl group of triglyceride. The transesterification is then completed via a methoxide transfer. The process mechanism is almost similar to that of chemical transesterification through stepwise reaction of converting triglyceride, diglyceride, monoglyceride, methyl ester, and lastly glycerol. Parameters affecting transesterification reaction via supercritical-methanol process such as temperature, pressure, and molar ratio of alcohol to triglyceride have been discussed previously (Lee and Saka, 2010). It is also noted that the optimum temperature needed in order for the transesterification to occur lies within the range of $270{ }^{\circ} \mathrm{C}$ to $300{ }^{\circ} \mathrm{C}$ with a supercritical pressure of 
8.09 $\mathrm{Mpa}$ and higher. Although higher temperature has been proven to increase the transesterification rate (Saka and Kusdiana, 2001), isomerization of polyunsaturated methyl ester from cis-type to trans-type isomers as well as thermal decomposition has been observed (Imahara et al., 2008). In this situation, the reaction should be conducted below $300{ }^{\circ} \mathrm{C}$. Tan et al. (2009) reported the comparison between conventional catalyst (homogeneous and heterogeneous) and supercritical methanol using the same oil (purified palm oil). The result revealed that supercritical methanol reaction rate was 3 -folds higher compared to the conventional catalyst. Alternative alcohol such as ethanol, 1-propanol, 1-butanol, and 1-octanol have also been studied under supercritical condition (Warabi et al., 2004). However, due to the requirement of high temperature and pressure when only alcohol was employed, addition of co-solvent such as carbon dioxide, calcium oxide, propane, and hexane has been proposed to address this problem (Yin et al., 2008a). The addition of a small amount of catalyst and co-solvent in the reaction significantly reduced the amount of methanol and temperature required (Yin et al., 2008b). The reaction produced $98 \%$ yield of methyl esters within 10 min reaction time. Nevertheless, the reaction condition is still considered as energy intensive, and the addition of co-solvents resulting in increased reaction volume is less practical at large-scale.

\subsubsection{Supercritical carbon dioxide}

SC- $\mathrm{CO}_{2}$ is a potentially promising alternative to supercritical methanol. A distinctive advantage of $\mathrm{SC}-\mathrm{CO}_{2}$ is that supercritical condition can be achieved at mild temperature and pressure below the denaturation conditions of the enzyme. Final $\mathrm{CO}_{2}$ removal can easily be achieved by reducing the pressure level since the product and enzyme are not soluble in $\mathrm{CO}_{2}$. Thus, SC$\mathrm{CO}_{2}$ has the potential to be integrated into a continuous industrial enzymatic reactor for biodiesel production. The utilization of $\mathrm{SC}-\mathrm{CO}_{2}$ in enzymatic processes is further discussed in Section 5.

\subsection{Enzymatic catalyst}

Recent studies show that biocatalytic (enzymatic) process is more favorable than conventional catalyst (Aransiola et al., 2014). Lipases from different sources have been explored for their ability to convert lipid into biodiesel by means of enzyme immobilization (Christopher and Zambare, 2014). Figure 2 shows the general transesterification reaction using lipase catalyst. Enzymatic transesterification comprises four steps: i) the formation of enzyme-substrate complex by nucleophilic addition; ii) the proton transfer from conjugate acid of amine to alkyl oxygen atom of substrate; iii) the addition of oxygen atom from alcohol to the acyl-enzyme intermediate forming acylated enzymealcohol complex; and iv) the elimination of oxygen atom from the complex followed by the formation of FAME by proton transfer from conjugate acid of amine (Al-Zuhair et al., 2007). During the transesterification process, breakdown of triglyceride is performed via hydrolysis in the presence of water. However, if alcohol is in excess, lipase will accept alcohol as substrate and start converting lipid into biodiesel by following the bi-bi ping pong reaction (Fjerbaek et al., 2009). This can be explained by the fact that the catalytic site of lipase is hidden within the structure of its monomeric protein which is only exposed at the lipid-water interface (Nigam et al., 2014).

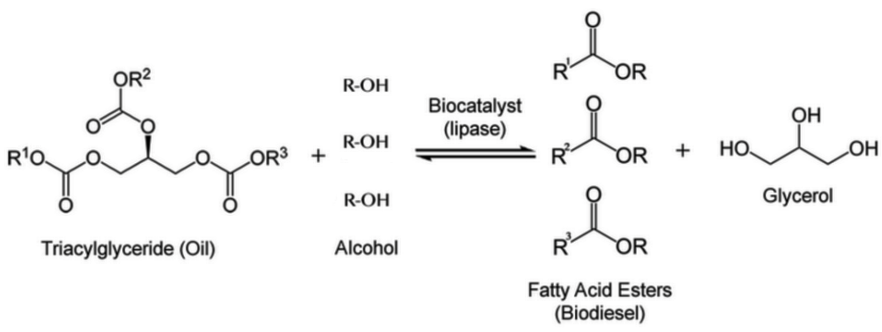

Fig.2. General transesterification reaction using lipase catalyst.

Enzymatic reaction offers significant benefits in terms of its low energy consumption and high compatibility with high FFA content of feedstock. It also provides ease of product separation and catalyst recovery as well as good regeneratability (Fukuda et al., 2001). Lipase requires water molecules in order to be activated for biodiesel production. Optimal water activity needed for lipase activation relies on the lipase origin, solvent used, and enzyme condition (suspended or immobilized) (Noureddini et al., 2005; Oda et al., 2005).

The enzymatic transesterification process is normally carried out in the presence of an organic solvent to obtain a homogenous reaction mixture (Lu et al., 2008; Park et al., 2008). Lipases can be deactivated by a short chain alcohol (e.g., methanol and ethanol) as reported by several researchers (Watanabe et al., 2002; Du et al., 2004; Modi et al., 2006). It has been reported that tert-butanol is more suitable as an acyl acceptor (Li et al., 2006, 2007; Raita et al., 2011). Besides reducing the inhibition factor, tert-butanol stabilizes and promotes enzyme activity mainly due to the moderate polar properties of tert-butanol that allow complete solubilization of methanol and glycerol ( $\mathrm{Li}$ et al., 2006). However, tertbutanol is least preferred to short chain alcohol in large scale processes due to their relatively expensive price. A solvent-free system has been employed to synthesize biodiesel at a comparable productivity (BélafiBakó et al., 2002; Shah and Gupta, 2007; Ognjanovic et al., 2009), however, a lower reaction rate due to poor mass transfer efficiency between the oil/methanol and the enzyme was observed. To enhance the mass transfer rate in a solvent-free system, an interconnected porous reactor that offers convective mass transfer property has been proposed Such a reactor is further highlighted in Section 4. New technologies and strategies to address the issues of high enzyme cost and slow reaction rate are reviewed in Section 5.

\section{Strategies for lipase immobilization}

Enzyme immobilization on support matrix for biodiesel processing has been rapidly gaining its pace. Immobilization technology has been known to shelter and/or stabilize enzymes against harsh environments (e.g., $\mathrm{pH}$, temperature, chemicals, and agitation), reduce contamination of products (Mateo et al., 2003), and more importantly promote the recovery and reuse of enzyme in a continuous process (Husain et al., 2011; Misson et al., 2015a). There are three strategies of enzyme immobilization: (i) direct immobilization on modified surfaces; (ii) immobilization on beads; and (iii) immobilization of enzymes on monoliths (He et al., 2009). Some disadvantages were reported for both direct immobilization and immobilization on beads namely; (1) long diffusion times; (2) enzyme denaturation; (3) and the need of high enzyme load during immobilization (Park and Clark, 2002; Peterson et al., 2002; Křenková and Foret, 2004). The key component in producing high quality immobilized enzyme is the appropriate selection of immobilization techniques and support material to be used that permit high enzyme activity whilst reducing inhibition effects, promotes wide ranges of $\mathrm{pH}$ and temperature tolerance, and high stability under the constrains imposed by the substrate medium (Noureddini et al., 2005; Shao et al., 2008). Enzyme has been employed in various types of support materials including natural/synthetic polymers or inorganic materials as reported by Datta et al. (2012) or advanced nanostructured materials as reviewed by Misson et al. (2015b). Understanding the strategies of enzyme immobilization is important in order to preserve the native functionality of a biocatalyst. Enzyme immobilization can be done by physical adsorption, covalent binding, cross linking enzyme aggregate (CLEA), and entrapment methods (Tan et al., 2010b).

\subsection{Physical adsorption}

The adsorption of enzymes onto insoluble supports occurs through weak forces like Van der Walls or hydrogen bonding under suitable conditions such as optimal $\mathrm{pH}$ and ionic strength (Jegannathan et al. 2008). Adsorption has been widely employed for lipase immobilization due to the simple and inexpensive process as well as the potential reuse of carrier. The standard procedure for adsorption onto solid carriers includes dissolving lipase in a buffer solution with gentle mechanical mixing. Salis et al. (2003) revealed that lipase adsorption took a longer time by displacing other proteins with lower affinity for the support. Among the supports used for lipase adsorption are silica (Blanco et al., 2004), 
styrene-divinylbenzene copolymer (Dizge et al., 2009b), chitosan based support (Badgujar et al., 2013; Nwagu et al., 2013), carbon monolith (Luangon et al., 2012), activated carbon (Ramani et al., 2012), polysulfone membrane (Yujun et al., 2008), aldehyde-resin (Mendes et al., 2011), and polypropylene (Gitlesen et al., 1997). The support properties such as hydrophobicity, particle size, and porosity significantly affect the enzyme binding capacity and activity upon immobilization (Palomo et al., 2002). Low immobilized lipase activity is usually attributed to the alteration in structural conformation of the enzyme, low enzyme immobilization yield, and reduction in the ability of hydrophobic substrates to reach the active site of lipase (Xavier Malcata et al., 1990). Hydrophobic interaction between lipase and the support may also occur resulting in lipase adsorption as reported by Gitlesen et al. (1997).

The pore diameter of mesoporous and macroporous supports affects the lipase immobilization yield, where the degree of immobilization yield increases with increasing pore diameter to a certain point (Lauren et al., 2013). Adsorption isotherm illustrating the trend of support affinity for lipase can be used to study lipase-support interaction and to screen for a suitable support for lipase immobilization (Blanco et al., 2004). Despite the advantages of simple process and mild reaction conditions (Jesionowski et al., 2014), lipase attachment through adsorption suffers a major drawback that is leakage due to the weak binding between lipase and carrier thus reducing the enzyme recyclability.

\subsection{Covalent binding}

Enzyme immobilization via covalent binding provides a strong attachment of enzymes on the support matrix. As a result, covalent binding can potentially hinder enzyme leakage upon immobilization. Binding can occur through the interaction between the functional groups available on the surface of the enzyme and carrier. Functional groups such as amino, carboxylate, thiol, and hydroxyl are present on enzyme surfaces located in lysine, arginine, glutamic, and aspartic acid residues (Sakai et al., 2010). The functional groups on the carriers are introduced via surface functionalization (Misson et al., 2016) or activation using coupling agent (Xie and Ma, 2009). Coupling agents determine the type of functional group deposited on the support surface. The commonly used coupling agent glutaraldehyde introduces aldehyde groups that will interact with lipase amino group (Barbosa et al., 2012). Epichlorohydrin, on the other hand, will bind to amino, hydroxyl, and sulfhydryl groups of lipase (Rodrigues et al., 2008; Nigam et al., 2014). Many other functional groups of lipase have also been explored for covalent immobilization. Knezevic et al. (2006) reported lipase immobilization on Eupergit $\mathrm{C}$ support via carbohydrate moiety demonstrating nearly 2 -fold higher enzyme stability than conventional method and 18 -folds higher than free lipase. Successful implementations of this technique have also been reported for other types of enzyme such as invertase (Prodanović et al., 2001) and glucoamylase (Milosavić et al., 2007). Support surface modifications using a spacer arm have also shown positive impacts on the enzyme stability (Bayramoglu et al., 2005; Ozyilmaz, 2009). Modifications of the length of the spacer arm can be achieved through a series of chemical reactions as demonstrated by Arica et al. (2009) and (2000). Despite providing strong binding and enhancing enzyme stability against leakage (Rodrigues et al., 2013), covalent binding requires rigorous conditions during immobilization that may potentially reduce the lipase activity thus rendering the technique less economical.

\subsection{Cross linking enzyme aggregates (CLEA)}

CLEA is a carrier-free enzyme immobilization technique first discovered in 1960s (Sheldon, 2007). The enzyme acts as a carrier and precipitates forming a high concentration of enzymes (Hanefeld et al., 2009). The immobilization approach includes enzyme precipitation by the addition of salts/watermiscible organic solvents/non-ionic polymer (e.g., acetone, ammonium sulphate, ethanol or polyethylene glycol - PEG) followed by the addition of a cross-linker (e.g., glutaraldehyde) (Jegannathan et al., 2008; Hanefeld et al., 2009). It has been known that the addition of additives such as surfactants and amines enhances the activity of the immobilized enzyme (Sheldon, 2007; Nigam et al., 2014). The purification and immobilization processes are combined into a single step, thus simplifying the process and lowering the production cost. The successful applications of CLEA in biodiesel production have been demonstrated previously (Kumari et al., 2007; Raita et al. 2011; Sheldon, 2011; Lai et al., 2012). Hilal et al. (2004) reported a new approach by embedding CLEA onto a microporous polymeric membrane producing an effective lipase-embedded biocatalytic membranes. However, CLEA displays some drawbacks when it is used in a heterogeneous reaction. As the size of CLEA is usually below $10 \mu \mathrm{m}$ (Jegannathan et al., 2008), the enzyme activity declines drastically, and separating CLEA from the product can be problematic (Cao et al., 2003).

\subsection{Entrapment (physical immobilization)}

Entrapment, as in the case of a sol gel technique, involves mixing of enzymes in a monomeric solution before the polymerization occurs. Enzymes are protected against environmental exposure within the polymeric matrix. The porosity of an enzyme-immobilized polymer can be varied based on the polymerization conditions, for instance, the drying conditions (Sheldon, 2007). The gel formed can be classified into three categories in the order of decreasing densities namely; xerogels, ambigels, and aerogels, respectively. Lipase has also been entrapped in methylenebisacylamide, chitosan, cellulose, agarose, calcium alginate, and kappa carrageenan (Ghaly et al., 2010; Nigam et al., 2014). It is important to note that hydrophilic carriers may reduce the activity of an enzyme hence is not recommended for lipase entrapment (Reetz et al. 1996). As the enzyme is entrapped during the polymerization process, it is also important that the reaction conditions do not denature or damage its structural conformation. Additionally, additives such as surfactants and crown ethers have proven to increase lipase loading capacity and activity (Sheldon, 2007). Soares et al. (2004) demonstrated the activity of entrapped lipase in the presence of PEG of three times higher than without additives. Although the entrapment method is cheap, fast, and involves mild conditions (Lalonde and Margolin, 2008), mass transfer resistance and enzyme leakage have hindered its successful application. Table 2 compares the different techniques involved in lipase immobilization.

Although enzyme immobilization offers various advantages, the conversion of lipid into biodiesel involves large molecules such as triglyceride thus diffusion of such molecules can be problematic. On the other hand, large pore size can lead to internal mass transfer limitations as the effective contact between the enzyme and substrate is reduced. The formation of a glycerol film in a continuous porous biodiesel reactor has been reported previously (Fjerbaek et al., 2009). Thus, appropriate selection of support matrices and methods for enzyme immobilization is vital in order to produce highly efficient biodiesel pathways. Selection of support matrices is dependent upon a number of factors such as mechanical strength, microbial resistance, thermal stability, chemical durability, hydrophobicity, ease of regeneration, loading capacity, and production cost (Jegannathan et al., 2008).

\section{Monolithic bioreactor for biodiesel production}

Various types of support matrix for enzyme immobilization have been used for the biocatalytic conversion of lipid into biodiesel. STR in which the immobilized enzyme is suspended in a liquid medium is a simple bioreactor design consisting of a reactor vessel and a propeller. STR offers high heat removal and excellent mass transfer characteristics due to the very small particle size, hence the increase in surface area. However, STR needs multiple purification steps which are inconvenient in a large scale application. PBR can be operated in either batch or continuous mode by recirculating the reaction mixture. In PBR, substrate flows concurrently upward or downward over the immobilized enzyme. However, a downward substrate flow is not always preferable due to poor oxygen transfer and high pressure drop caused by the compressed enzymatic bed support (Fjerbaek et al., 2009). PBR is often limited by large biomolecular assemblies, highly concentrated feedstocks, reduced liquid-solid contacting efficiency, and bed instability (Stickel and Fotopoulos, 2001). Figure 3 shows the schematic diagram of biodiesel production route via STR and PBR.

In the continuous search for suitable processes of fabricating enzymatic bioreactors, scientists have discovered the idea of using structured packing instead of randomly packed bed (Strancar et al., 2002). To date, various types of structured packing material are available such as organic 
Table 2.

Various lipase immobilization techniques.

\begin{tabular}{|c|c|c|c|c|c|c|c|c|}
\hline Source of enzyme & $\begin{array}{l}\text { Type of } \\
\text { support }\end{array}$ & $\begin{array}{l}\text { Method of } \\
\text { immobilization }\end{array}$ & $\begin{array}{l}\text { Acyl } \\
\text { acceptor }\end{array}$ & $\begin{array}{l}\text { Oil } \\
\text { feedstock }\end{array}$ & Reaction condition & $\begin{array}{c}\text { FAME } \\
(\%)\end{array}$ & Recyclability & Reference \\
\hline Candida sp. 99-125 & Textile & Adsorption & Methanol & Lard & $\begin{array}{l}8 \mathrm{ml} \mathrm{n} \text {-hexane as solvent, } 20 \% \text { water } \\
\text { based on the fat weight, temperature } 40 \\
{ }^{\circ} \mathrm{C} \text {, three-step addition of methanol, } \\
\text { solvent free }\end{array}$ & $87.4 \%$ & $\begin{array}{l}\text { Stable when } \\
\text { used repeatedly } \\
\text { for } 180 \mathrm{~h}\end{array}$ & Lu et al. (2007) \\
\hline Thermomyces lanuginosa & Immobead 150 & Adsorption & Methanol & Soybean oil & $\begin{array}{l}\text { temperature } 40{ }^{\circ} \mathrm{C} \text {, and three-step } \\
\text { addition of methanol, solvent free, } 9.65 \mathrm{~g} \\
\text { soybean oil }\end{array}$ & $90 \%$ & N/A* & Du et al. (2005) \\
\hline Candida antarctica & Acrylic resin & Adsorption & Methanol & $\begin{array}{l}\text { Cotton seed } \\
\text { oil }\end{array}$ & $\begin{array}{l}24 \mathrm{~h} \text { at } 50{ }^{\circ} \mathrm{C} \text { with a reaction mixture } \\
\text { containing } 32.5 \% \text { tert-butanol as solvent, } \\
13.5 \% \text { methanol, } 54 \% \text { oil }\end{array}$ & $95 \%$ & $\begin{array}{l}\text { Stable when } \\
\text { used repeatedly } \\
\text { for } 500 \mathrm{~h}\end{array}$ & Royon et al. (2007) \\
\hline Thermomyces lanuginosa & Immobead 150 & Adsorption & Methanol & Soybean oil & $\begin{array}{l}\text { methanol/oil molar ratio } 3.6: 1 \text {, } \\
\text { temperature } 40{ }^{\circ} \mathrm{C}, 150 \mathrm{r} / \mathrm{min} \text {. } \\
\text { tert-butanol as solvent }\end{array}$ & $97 \%$ & $\begin{array}{l}\text { Stable when } \\
\text { used repeatedly } \\
\text { for } 120 \text { cycle }\end{array}$ & Wang et al. (2006) \\
\hline Thermomyces lanuginosa & $\begin{array}{l}\text { Toyopearl AF- } \\
\text { amino-650M }\end{array}$ & Covalent & Ethanol & Palm oil & $\begin{array}{l}\text { Ethanol/oil ratio } 18: 1,48 \mathrm{~h} \text { at } 45^{\circ} \mathrm{C} \text {, } \\
\text { agitation speed } 180 \mathrm{rpm}\end{array}$ & $100 \%$ & N/A & Mendes et al. (2011) \\
\hline Thermomyces lanuginosus & $\begin{array}{l}\text { (STY-DVB) } \\
\text { copolymer }\end{array}$ & Covalent & Methanol & Canola oil & $\begin{array}{l}50^{\circ} \mathrm{C} \text { in } 24 \mathrm{~h} \text { reaction, } 3 \text { step addition of } \\
\text { methanol, solvent free, } 6: 1 \text { methanol/oil }\end{array}$ & $97 \%$ & $\begin{array}{l}\text { No changes after } \\
10 \text { repeated } \\
\text { batch reactions }\end{array}$ & Dizge et al. (2009b) \\
\hline Thermomyces lanuginosus & $\begin{array}{l}\text { Aldehyde } \\
\text { Lewatit beads }\end{array}$ & Covalent & Ethanol & Soybean oil & $\begin{array}{l}7.5: 1 \text { ethanol/oil, } 4 \% \text { water, } 10 \mathrm{~h} \text { at } 30^{\circ} \mathrm{C} \\
\text { in n-hexane }\end{array}$ & $100 \%$ & $\begin{array}{l}\text { Similar activity } \\
\text { after } 3 \text { batches }\end{array}$ & Rodrigues et al. (2010) \\
\hline Thermomyces lanuginosus & Olive pomace & Covalent & Methanol & Pomace oil & $\begin{array}{l}25^{\circ} \mathrm{C} \text { in } 24 \mathrm{~h} \text { reaction. } 3 \text { step addition, } \\
\text { solvent free. 1:6 methanol/oil, }\end{array}$ & $93 \%$ & $\begin{array}{l}\text { Similar activity } \\
\text { after } 10 \text { batches }\end{array}$ & Yucel (2011) \\
\hline Penicillium expansum & N/A & Cross-linked & Methanol & $\begin{array}{l}\text { Microalgae } \\
\text { oil }\end{array}$ & $\begin{array}{l}0.5 \mathrm{~g} \text { algal oil was mixed with } 1.0 \mathrm{ml} \mathrm{IL} \\
\text { with addition of distilled water }(15 \mu \mathrm{L}) \text {, } \\
3: 1 \text { methanol/oil, at } 50^{\circ} \mathrm{C} \text { at a speed of } \\
220 \mathrm{rpm} \text { for } 48 \mathrm{~h}\end{array}$ & $85.7 \%$ & N/A & Lai et al. (2012) \\
\hline Pseudomonas cepacia & N/A & Cross-linked & Ethanol & $\begin{array}{l}\text { Madhuca } \\
\text { indica oil }\end{array}$ & $\begin{array}{l}4: 1 \text { ethanoi/oil, } 40^{\circ} \mathrm{C} \text { for } 2.5 \mathrm{~h} \text { with a } \\
\text { constant shaking at } 200 \mathrm{rpm}\end{array}$ & $92 \%$ & N/A & Kumari et al. (2007) \\
\hline Candida sp. 99-125 & $\begin{array}{l}\text { Macroporous } \\
\text { silica }\end{array}$ & Cross-linked & Ethanol & $\begin{array}{l}\text { Jatropha } \\
\text { oil }\end{array}$ & $\begin{array}{l}40{ }^{\circ} \mathrm{C} \text { for } 24 \mathrm{~h}, 0.21 \mathrm{~g} \text { oil } / 0.175 \mathrm{ml} \\
\text { ethanol, } 1.5 \mathrm{ml} \text { cylcohexane }\end{array}$ & $72 \%$ & $\begin{array}{l}\text { Maintain more } \\
\text { than } 85 \% \text { of } \\
\text { initial activity } \\
\text { after } 16 \text { days }\end{array}$ & Jiang et al. (2014) \\
\hline Pseudomonas cepacia & $\begin{array}{l}\text { Sol-gel } \\
\text { support }\end{array}$ & Entrapment & Methanol & Soybean oil & $\begin{array}{l}35^{\circ} \mathrm{C}, 1: 7.5 \mathrm{oil} / \mathrm{methanol} \text { molar ratio, } \\
0.5 \mathrm{~g} \text { water in } 1 \mathrm{~h} \text { reaction }\end{array}$ & $67 \%$ & $\begin{array}{l}\text { Decrease to } \\
\text { below } 50 \% \text { after } \\
12 \text { cycles }\end{array}$ & Noureddini et al. (2005) \\
\hline
\end{tabular}

*N/A: not available

and inorganic supports called "monolith" (Ameur et al., 2014), "sandwich packing" (Kashani et al., 2005), "open cross flow structures" (OCFS), and "closed cross flow structures" (CCFS) (Pangarkar et al., 2009). These materials show several advantages in many applications such as biochromatography, membrane separation, effective reaction column, and potentially as support matrices for enzyme immobilization. Enzyme immobilization employing monolith as the support matrix has been shown to possess a number of advantages over PBR and STR (Huang et al., 2008; Dizge et al., 2009a). Monolithic reactor provides several predominating features, including lower bed pressure drop, better mass transfer performance, higher specific surface area, lower axial dispersion, and back mixing as well as lower investment cost and reliability to scale-up (Santos and Costa, 2009).
Moreover, monolithic reactor allows higher substrate flow rate compared to conventional PBR thus resulting in increased productivity. The monolith concept was first mentioned in the early 1950s but did not gain popularity due to the low mechanical stability limitation at that time (Svec, 2010). The orthodox monolith was a structure made of metal or ceramic with a large number of straight, identical, and parallel channels. Monoliths fabricated from polymers termed 'monolithic polymers' were first introduced by Hjertén et al. (1989). Later, Svec and Fréchet (1992) published their first paper on 'continuous porous rods' revealing the potential of monolithic technology in the field of bimolecular separation. Since then, a vast number of studies have been conducted to test the applicability of monolithic polymers in biocatalytic separation (Gusev et al., 1999; Tanaka et al., 2002; Cabrera, 2004; Guillarme et al., 2010; Lv et 
(a)

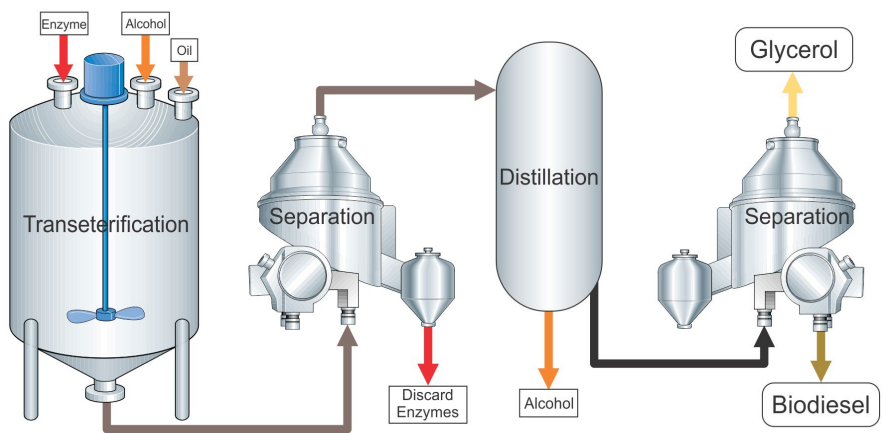

(b)

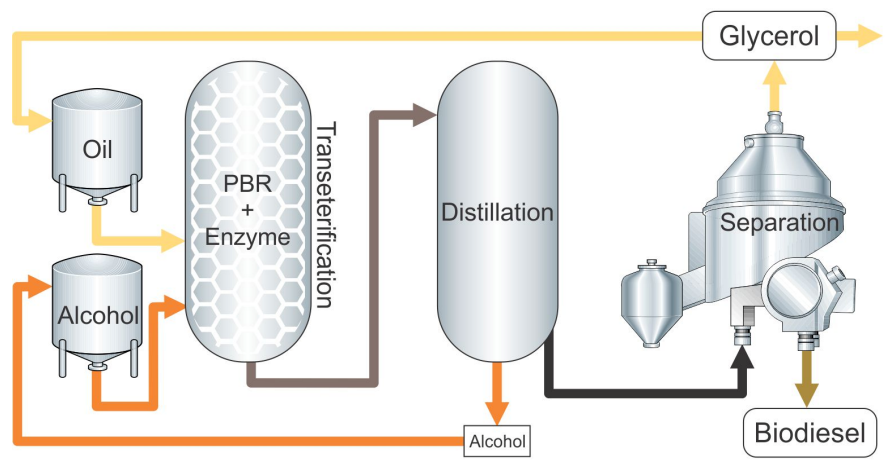

Fig.3. Biodiesel production route via (a) Stirred tank reactor (STR) and (b) Packed bed reactor (PBR).

al., 2014). Countless methods for the preparation of monolithic polymers have been reported in the literature. In 2010, a summary of different polymerization techniques developed to fabricate monolithic polymer was published (Svec, 2010). Regardless of the methods used, the fundamental concept of monolith preparation is a reaction that takes place within a mold containing monomers, porogenic solvents, and a radical initiator, and initiated by heat. The selection of monomer/s used in the polymerization reaction is important as it reflects the final functionality on the monolith surface.

\subsection{Hydrodynamics of monolith}

The morphology of a monolithic polymer is basically a single interconnected porous structure. The geometry of the monolith channels is usually rectangular; however, more complex geometries also exist (Williams, 2001). Figure 4 shows the differences in internal structure of a packed column and a monolithic column. Alternatively, the monolith functional group, shape, and size of pore can be readily altered by modifying the type and ratio of monomer/s and porogenic solvent according to the user's preferences hence the versatility of the monolith. Understanding the hydrodynamics of a monolithic reactor is crucial in achieving high lipid to biodiesel conversion rate (Krishna and Sie, 1994). The physical properties and superficial velocity of liquid as well as the type of structured packing used are the main hurdles that affect the hydrodynamic parameters such as liquid-holdup volume, flow rate, and pressure drop (Roy et al., 2004). Besides the high conversion rate, other factors such as low pressure drop, high substrate flow rate, lower axial dispersion, and back mixing, higher specific surface area, and high mass transfer rate are also desirable in designing a monolithic biodiesel reactor. The main difference between a conventional reactor and a monolithic reactor is the internal structure of the monolith. Monolith is a piece of porous material with a significant amount of interconnected pores thus allowing the mobile phase to flow through the column by convection at a relatively very low pressure. (a)

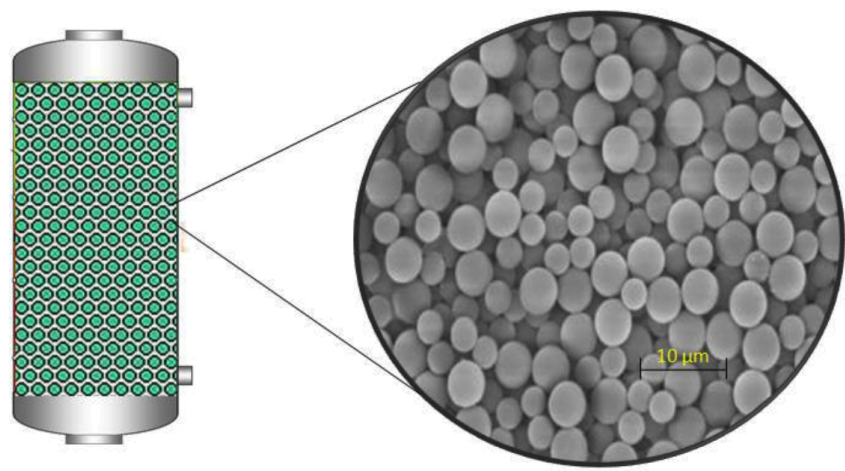

(b)

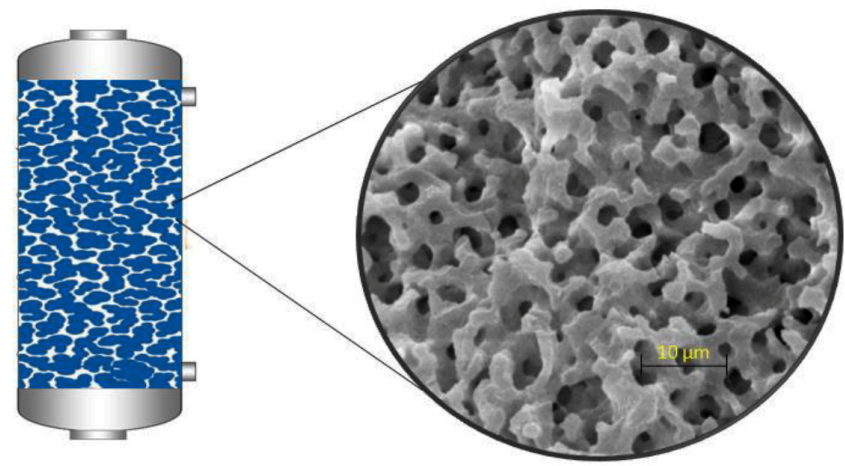

Fig.4. The difference in internal structure of (a) packed column (b) monolith column

\subsection{Organic monolith}

In 1992, Svec and Fréchet pioneered the in situ preparation of monolithic polymer within the confine of a standard stainless steel column. Discs cut from this monolithic polymer showed high permeability allowing fast separations of proteins (Tennikova et al., 1990). Since then, a multitude of studies have been carried out, and have made significant impacts on the separation technology. The diverse and relatively simple methodologies involved in organic monolith preparation have led to rapid advancement of the technology. Organic monoliths are commonly composed of methacrylate, acrylamide, and styrene monomers. To date, various methods for the preparation of monoliths can be found extensively in the literature such as free radical processes (thermally/photoinitiated/radiation), high internal phase emulsions, cryogels, living polymerizations (nitroxide mediated/organoterllerium initiators/atom transfer/ring-opening metathesis), polycondensation, and preparation of monoliths from soluble polymers (Svec, 2010). Thermal and photoinitiated radical polymerizations are the most commonly used methods and widely reported in the literature purportedly due to their simple processes.

In the last two decades, separation of large molecules such as protein in reversed-phase (Liu et al., 2009) and in ion-exchange (Chen et al., 2009) chromatography has been driven towards the utilization of organic polymer monoliths focusing on biocompatibility, morphology, and surface area enhancements. Recent approaches including the utilization of epoxy functional groups (Meador et al., 2005), incorporation of nanoparticles of varied functionalities (Liu et al., 2011), and the use of supramolecular templates (Wan et al., 2008) have been tested to enhance the performance of organic polymer monoliths. Organic polymer monoliths offer higher permeability, better biocompatibility, higher $\mathrm{pH}$ tolerance, and faster mass transfer rate in comparison with random packed polymer beads. However, some limitations such as poor heat dissipation, uneven pore size distribution, "wall channel" effect, and relatively low mechanical strength 
particularly during scale-up have also been reported (Ongkudon et al., 2014). The use of organic polymers as support matrices specifically for lipase immobilization has been demonstrated, however, its real application in biodiesel production is yet to be discovered. Dizge et al. (2009a) published their work on the immobilization of Thermomyces lanuginosus lipase onto a microporous polymeric matrix (MPPM) in different forms (powder, bead, and monolith) through the aldehyde functional group for the synthesis of biodiesel. This was an improvement made over their previous research findings (Dizge and Keskinler, 2008) where they developed a novel method utilizing polyglutaraldehyde and polyglutaraldehyde-activated poly(styrenedivinylbenzene) to immobilize lipase within hydrophilic polyurethane foams (Dizge et al., 2008). The MPPM was synthesized via poly-high internal phase emulsion (polyHIPE) technique using styrene, divinylbenzene, and polyglutaraldehyde. The highest immobilization efficiencies up to $89 \%$ were achieved by immobilizing $T$. lanuginosus lipase onto MPPM in monolithic forms. The optimal biodiesel yields were obtained from sunflower oil at $97 \%$ conversion, and the immobilized lipase retained its activity after 10 repeated batch reactions at $25^{\circ} \mathrm{C}$, each lasting $24 \mathrm{~h}$

Urban et al. (2012) demonstrated the application of enzyme-immobilized monolithic supports in both organic solvents and their biphasic mixtures with water (Urban et al., 2012). The poly (alkylmethacrylate-co-ethylene dimethacrylate) monolith was prepared based on their previous work (Eeltink et al., 2007). The monolith was functionalized with azlactone in a two-step grafting technique (Stachowiak et al., 2007) prior to the attachment of porcine lyophilized lipase. The optimized monolithic reactor was then used for the transeterification of soybean oil in pure organic solvent. The mixture of methanol and 2-methyl-2-propanol was used as acyl acceptor. The results obtained under the optimum operating conditions $\left(37^{\circ} \mathrm{C}\right.$ with $10 \mathrm{~min}$ of substrate residence time) were superior compared to those obtained using mobile lipases, and the enzyme activity was retained even after pumping through a solution of substrate equaling 1,000 reactor volumes.

\subsection{Inorganic monolith: silica}

Successful preparation of silica-based monolith including the synthesis of monolith with desired porous properties was reported by Nakanishi and Soga (1991) and (1992). Later on, a modification was made where they successfully eliminated the need for post treatment of monolith by substituting ammonium hydroxide with urea as the source of ammonia (Nakanishi et al., 2000). Fields (1996) was the first person to prepare a silicabased capillary column via in situ solidification of formamide solution of potassium silicate. Sol-gel approach is favorable in preparing silica-based monolithic columns in which the hydrolytic polycondensation of alkoxysilane forms the pores inside the silica rod. Sol-gel process allows users to fabricate silica monoliths according to their desired properties by regulating the rate of hydrolysis and condensation via the selection of suitable precursors, temperature, $\mathrm{pH}$, reactant concentration, incubation time, and type of catalyst. Tetramethoxysilane (TMOS), tetraethoxysilane (TEOS), and polyethoxydisiloxane (PEDS) are the most commonly used precursors. TMOS has been found to be superior to TEOS and PEDS in terms of pore distribution and surface area (Wagh et al., 1999). The problem that commonly occurs in sol-gel process is the insolubility of alkoxide precursors in water forming two separate phases when constituted together. This bottleneck can be overcome by using alcohol (Šefčik and McCormick, 1997) or PEG (Nakanishi et al., 2000) as the solubilizing agents. Although this process allows the silica-based monoliths to have excellent mechanical stability, their preparation is quite difficult.

Other methods have also been introduced including embedding particles inside the pores (Dulay et al., 1998), encapsulating silica particles within a polymeric backbone (Bakry et al., 2006), and using mixed alkoxysilanes within the confine of a capillary (Motokawa et al., 2006). Subsequent developments in phase separation techniques in addition to using hydrolysiscontrolling additives have made it possible to synthesize commercial silicabased monoliths. Like organic polymer monoliths, silica-based monoliths offer numerous advantages such as high mass transfer rate, excellent permeability, and low back pressure drop (Cabrera, 2004; Kato et al., 2005). A common property shared by all silica-based supports is that they can only operate in a certain range of $\mathrm{pH}(2-8)$ for a given time and degrade rapidly in certain mobile phases, such as in phosphate buffers (Shi et al., 2004). However, silica-based monolith is suitable for the separation of biomolecules of varied molecular sizes as it possesses a defined macro/meso-pores network apart from the ability to comprehend extreme temperatures of over $750^{\circ} \mathrm{C}$ (Bacskay et al., 2014).

Recently, silica-based monoliths have been adopted as support matrices for enzyme immobilization in biodiesel production (Yu et al., 2013). The utilization of silica-based monoliths in biodiesel production can be found widely in the literature. Anuar et al. (2013) immobilized Candida antarctica lipase on a silica monolith with $15 \mathrm{~cm}$ in length and $320 \mu \mathrm{m}$ in internal diameter using glutaraldehyde as a cross-linking agent. The optimized microreactors were used for the transesterification of lipid with atmospheric pressure photoionization (APPI) thus becoming the first demonstration of an online microreaction. The results showed that the reactor was reusable without a noticeable loss of activity up to 15 runs when operated at a room temperature and flow rates of $<1 \mu \mathrm{L} / \mathrm{min}$. Kawakami et al. (2011) demonstrated the use of n-butyl-substituted hydrophobic silica monolith as support matrices for the immobilization of Burkholderia cepacia lipase to convert crude jatropha oil into biodiesel. A biodiesel yield of $90 \%$ was obtained in a 12-h batch reaction while in continuous production; a biodiesel yield of $95 \%$ was attained at a low flow rate of $0.6 \mathrm{~mL} / \mathrm{h}(2.79 \mathrm{~g}$-lipase $\mathrm{h} / \mathrm{mL})$. Approximately $80 \%$ of the initial yield was retained even after $50 \mathrm{~d}$ of continuous operation. A number of papers published on silica-based lipase immobilization for the production of biodiesel can be found elsewhere (Kawakami et al., 2007 2009, 2012; Shakeri and Kawakami, 2008).

\section{Supercritical carbon dioxide-based enzymatic bioreactor for biodiesel production}

The development of a sustainable production technology for biodiesel is significantly influenced by the cost of raw materials, pre-treatment processes, and catalysts used which can reach up to $60 \%$ of the overall cost (Baskar and Aiswarya, 2016). Numerous alternatives have been explored to overcome the high cost-related factors in biodiesel production including synergistically fusing $\mathrm{SC}-\mathrm{CO}_{2}$ technology and enzymatic bioreactor (Taher et al., 2011b and 2014).

\subsection{Inorganic enzymatic reactor with $\mathrm{SC}-\mathrm{CO}_{2}$}

Among the available catalytic transesterification processes for biodiesel production, enzyme-catalyzed process is more attractive due to the simplicity, being non-toxic, and low energy consumption. However, the slow reaction kinetics has hindered the application of this technology at a commercial scale. Moreover, the use of organic solvents in the reaction raises concerns due to its volatility, toxicity, and flammability issues (Wen et al., 2009). The integration of enzymatic catalytic processes with SC- $\mathrm{CO}_{2}$ technology offers, in addition to the non-flammable and nontoxic features, a cheaper alternative to the conventional method due to the abundant natural carbon dioxide gases. SC- $\mathrm{CO}_{2}$ diffuses easily into solid matrices and drastically enhances the diffusivity of the dissolved mixture. The solvation properties of SC- $\mathrm{CO}_{2}$ can easily be manipulated by varying the temperature and pressure of the reaction. These features allow simple separation of product and unreacted reagents by decreasing the temperature and pressure to create two distinct liquid phases at atmospheric conditions (Reverchon and De Marco, 2006), hence allowing $\mathrm{CO}_{2}$ to be recycled back into subsequent reactions. Moreover, $\mathrm{SC}-\mathrm{CO}_{2}$ integration with enzymatic reactor has been proven to address the issues related to high temperature and high pressure requirements in noncatalytic supercritical techniques and the slow reaction rate associated with enzymatic production route while retaining the advantages of both techniques. The mass transfer rate is extensively increased due the high solvation properties of $\mathrm{SC}-\mathrm{CO}_{2}$ allowing homogenous mixture of oil/immobilized enzyme/methanol, increased interaction with the active sites of an enzyme, hence the increase in reaction rate. Figure 5 shows the visual observation of the mixture under different pressures.

\subsection{Biodiesel production in supercritical enzymatic reactor}

Rodrigues et al. (2011) reported the continuous biodiesel production using virgin and waste sunflower cooking oil as feedstocks catalyzed by Lipozyme TL-IM in SC- $\mathrm{CO}_{2}$ condition. A FAME yield of > $98 \%$ was 

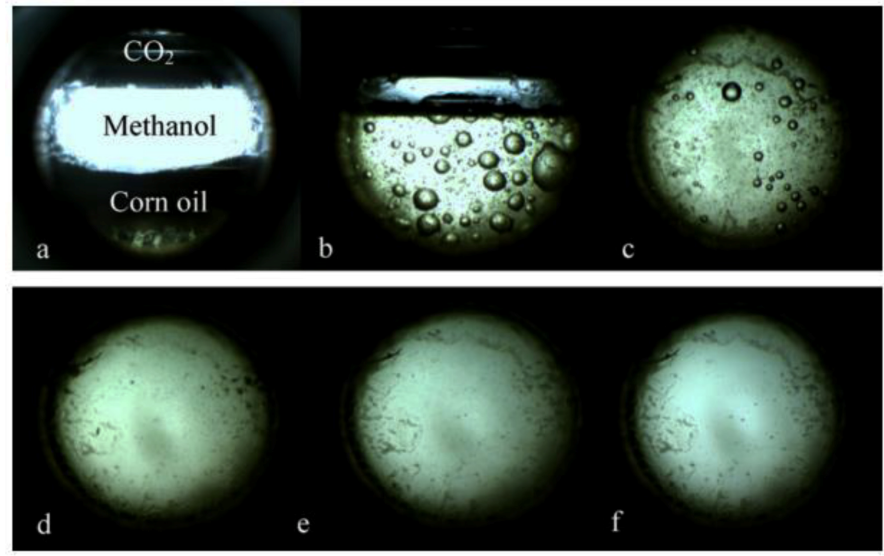

Fig.5. Visual observation of corn oil, methanol and $\mathrm{CO} 2$ mixture at different pressures at $55^{\circ} \mathrm{C}$. (a) $0.102 \mathrm{MPa}$, (b) $3 \mathrm{M} \mathrm{Pa}$, (c) $7 \mathrm{MPa}$, (d) $11 \mathrm{MPa}$, (e) $20 \mathrm{MPa}$, (f) $35 \mathrm{MPa}$. (Adopted from Ciftci and Temelli (2011)).

obtained at $20 \mathrm{MPa}, 40{ }^{\circ} \mathrm{C}$ temperature, 20 s residence time, and oil to methanol molar ratio of 1:24. The efficiency of Lipozyme TL-IM, however, decreased when waste sunflower cooking oil was used. Ciftci and Temelli (2011) optimized the biodiesel production from corn oil in a SC- $\mathrm{CO}_{2}$ bioreactor using immobilized lipase (Novozym 435) by varying the operating conditions using response surface methodology (RSM) yielding $93.3 \pm 1.1 \%$ FAME at $19.4 \mathrm{Mpa}, 62.9{ }^{\circ} \mathrm{C}, 7.03$ substrate mole ratio, and $0.72 \mathrm{~L} / \mathrm{min} \mathrm{CO}_{2}$ flow rate. In their recent study using a batch reactor, the highest FAME content of $81.3 \%$ was obtained at $15 \%$ enzyme loading, $60{ }^{\circ} \mathrm{C}$ temperature, 1:6 substrate mole ratio, $10 \mathrm{Mpa}$, and $4 \mathrm{~h}$ reaction time. Lozano et al. (2011) demonstrated that continuous biodiesel production from triolein with immobilized $C$. antarctica lipase B (Novozym 435) coated with an ionic liquid (IL) in $\mathrm{SC}-\mathrm{CO}_{2}$ system was better than batch process with the highest biodiesel yield of $98.6 \%$ obtained after $6 \mathrm{~h}$. They also reported that coating immobilized lipases with IL improved its operational stability. A yield of up to $85 \%$ was observed even after 12 cycles of $4 \mathrm{~h}$ reaction at $60^{\circ} \mathrm{C}$ and $180 \mathrm{bar}$. Lozano et al. (2007) reported the use of immobilized C. antarctica lipase B (CALB) on monolith-supported IL phases (M-SILPs) for the continuous synthesis of citronellyl propionate in $\mathrm{SC}-\mathrm{CO}_{2}$ condition by transesterification. The catalytic activity of the mini-flow-bioreactors remained practically unchanged for 7 operational cycles of $5 \mathrm{~h}$ each in different supercritical conditions. The best results were obtained when the most hydrophobic monolith, M-SILP-8-CALB, was used at $80{ }^{\circ} \mathrm{C}$ and $10 \mathrm{MPa}$, reaching a total of $35.8 \times 10^{4} \mathrm{~mol}$ product $/ \mathrm{mol}$ enzyme. The results significantly exceeded those obtained using PBRs with supported silica-CALB-Si-4 catalyst under the same experimental conditions.

These results prove that monolithic reactors, as discussed in Section 4, offer more advantages over the conventional supports. Therefore, it is of great interest to further optimize monolithic supports for lipase immobilization in a $\mathrm{SC}-\mathrm{CO}_{2}$ system. Generally, to ensure successful conversion of lipid into biodiesel using this system, the required conditions include temperature (40$60{ }^{\circ} \mathrm{C}$ ), pressure $(10-20 \mathrm{Mpa}$ ), methanol to oil ratio (more than 1:6 ratio, although excess methanol is problematic), and flow rate of $\mathrm{CO}_{2}(<0.1 \mathrm{~L} / \mathrm{min})$. In addition to the aforementioned conditions, selection of enzyme also plays an important role as some enzymes may not be compatible with this process. It has been suggested that the interaction between $\mathrm{CO}_{2}$ and the enzyme (free amine groups) at high pressure and temperature will lead to a gradual change in enantioselectivity of the enzyme (Matsuda et al., 2004). The primary advantage of utilizing enzymatic $\mathrm{SC}-\mathrm{CO}_{2}$ reactors over conventional techniques (chemical solvent, organic solvent, and free-solvent systems) is improved reaction rate; less than $8 \mathrm{~h}\left(\mathrm{SC}-\mathrm{CO}_{2}\right.$ system) and more than $24 \mathrm{~h}$ (conventional system) for a complete reaction. Studies have also been conducted on the effect of reaction conditions towards lipase activity. Lanza et al. (2004) reported that the increase in temperature and density of $\mathrm{CO}_{2}$ resulted in loss of enzyme activity while the $\mathrm{CO}_{2}$ decompression rate had no significant effect. It has been suggested that the magnitudes of pressure, temperature, decompression rate of $\mathrm{CO}_{2}$, and exposure time needed to inactivate the enzyme strongly depend on the nature and source of enzyme, as well as whether the enzyme is in its native or immobilized form. Figures 6 and 7 show the schematic diagrams of batch and continuous processes in $\mathrm{SC}-\mathrm{CO}_{2}$, respectively.

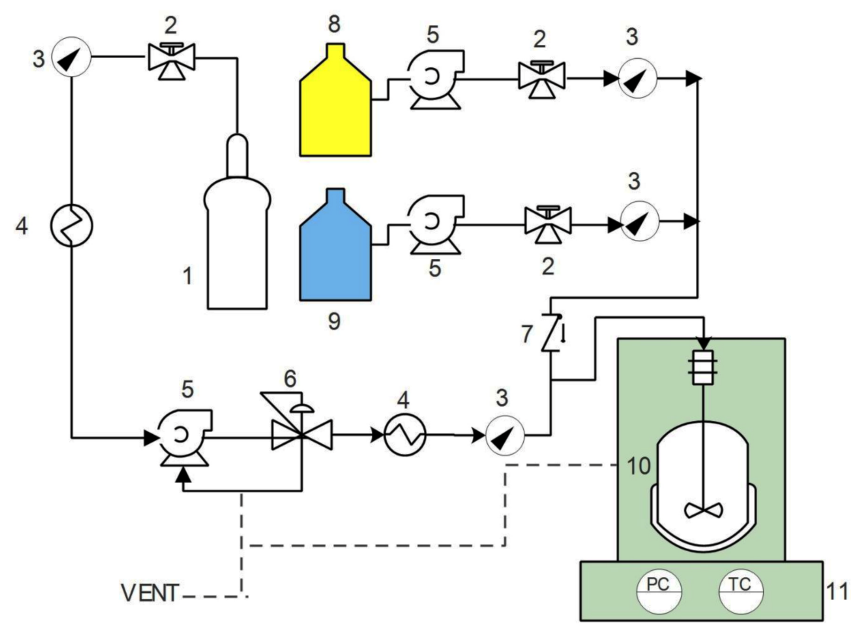

Fig.6. Schematic diagram of a batch SC-CO2 bioreactor. (1) $\mathrm{CO} 2$ cylinder; (2) control valve; (3) pressure gauge; (4) heat exchanger; (5) high pressured pump; (6) back pressure regulator; (7) check valve; (8) oil tank; (9) methanol tank; (10) stainless steel vessel equipped with stirrer; (11) oven equipped with temperature and pressure controller and indicator.

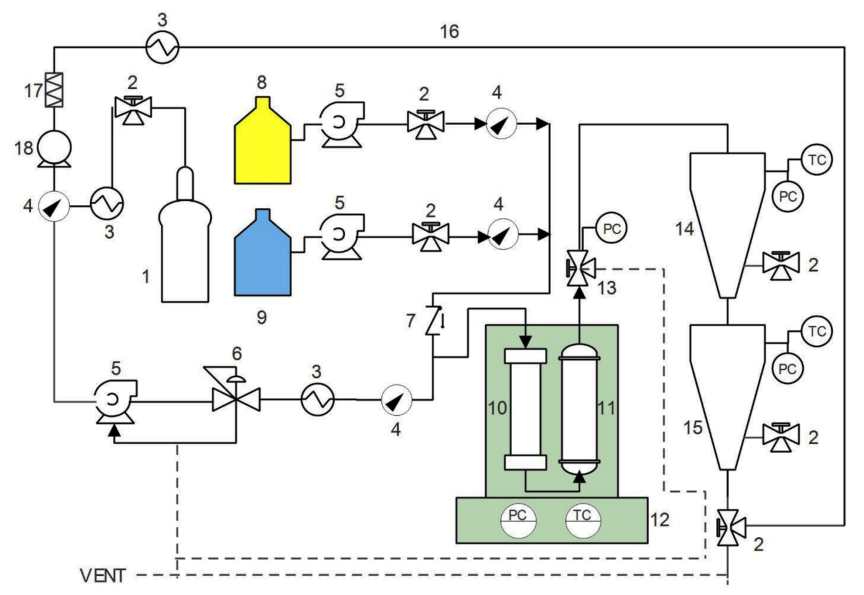

Fig.7. Continuous high pressure pilot scale biodiesel production system. (1) $\mathrm{CO} 2$ cylinder; (2) control valve; (3) heat exchanger; (4) pressure gauge; (5) high pressured pump; (6) back pressure regulator; (7) check valve; (8) oil tank; (9) methanol tank; (10) static mixer; (11) monolithic reactor; (12) oven equipped with temperature and pressure controller and indicator; (13) control valve with pressure indicator and controller; (10) static mixer; (14) (15) separator (cyclone); (16) carbon dioxide recycle loop; (17) filter; (18) compressor

\subsection{Oil extraction in supercritical enzymatic reactor}

Although enzymatic $\mathrm{SC}-\mathrm{CO}_{2}$ reaction has been demonstrated successfully, the uneconomical price of equipments has hindered the application of this technology at a commercial scale. A technology combining the process of biodiesel production and the extraction of oil from the same reaction system has been proposed. Chen et al. (2010b) investigated the extraction of triglyceride from powdered Jatropha curcas kernels by comparing $\mathrm{SC}-\mathrm{CO}_{2}$ technique with conventional soxhlet extraction method. The oil recovery was lower when using $\mathrm{SC}-\mathrm{CO}_{2}$ approach, however, the purity of triglycerides was better than that of 
Soxhlet extraction method. In a different study, Chen et al. (2010b) revealed an optimum oil yield of $43.51 \%$ extracted from J. curcas L. seeds using SC$\mathrm{CO}_{2}$ technology at $350 \mathrm{bar}, 333^{\circ} \mathrm{K}$, and a solvent to solid ratio value of 125:1. The concentration and extraction efficiency of triglycerides reached 657.1 $\mathrm{mg} / \mathrm{g}$ and $97.62 \%$, respectively. A comparison between conventional extraction (static solvent extraction) and $\mathrm{SC}-\mathrm{CO}_{2}$ extraction has been made by investigating the effect of biomass pretreatment prior to microalgae extraction (Taher et al., 2014), and the results showed that $\mathrm{SC}-\mathrm{CO}_{2}$ extraction was the most efficient method. Similar findings have also been reported by other researchers (Santana et al., 2012; Aresta et al., 2005; Soh and Zimmerman, 2011). Such an advancement in the SC- $\mathrm{CO}_{2}$ technology has led to many new strategies combining oil extraction and enzymatic reaction to produce biodiesel in a single $\mathrm{SC}-\mathrm{CO}_{2}$ bioreactor system. This technique effectively allows $\mathrm{SC}-\mathrm{CO}_{2}$ to be recycled back into the extraction unit without having to change to a different system, and substantially reduces the overall operating cost. Currently, only a limited number of reports on the integrated extraction/enzymatic SC-CO $\mathrm{CO}_{2}$ system are available (Al-Zuhair et al., 2012), highlighting the need for further optimization and improvement of the technology. Figure 8 shows an example of integrated extraction/enzymatic $\mathrm{SC}-\mathrm{CO}_{2}$ system.

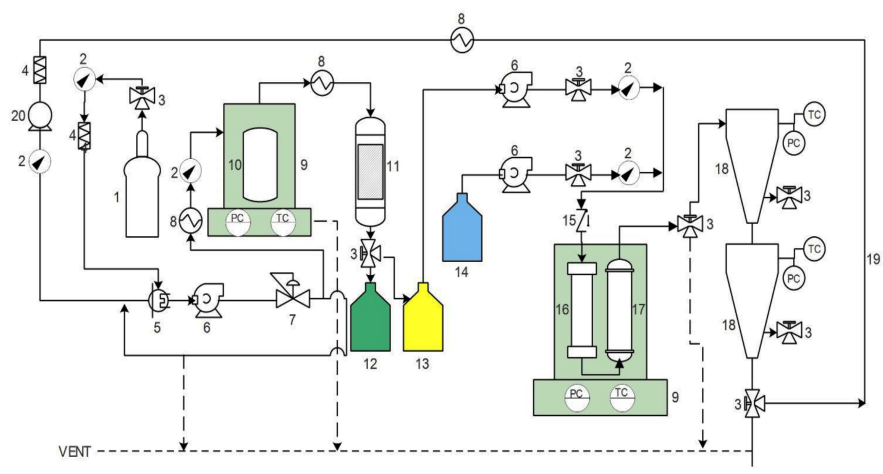

Fig.8. Schematic diagram of the integrated oil extraction-enzymatic reactor in SC-CO2. (1) $\mathrm{CO} 2$ cylinder; (2) pressure gauge; (3) control valve; (4) filter; (5) cooler; (6) high pressure pump; (7) back pressure regulator; (8) heat exchanger; (9) oven equipped with temperature and pressure controller and indicator; (10) extractor; (11) separator; (12) biomass collector; (13) oil and $\mathrm{CO}_{2}$ collector; (14) methanol tank; (15) check valve; (16) static mixer; (17) monolithic reactor; (18) separator (cyclone); (19) carbon dioxide recycle loop; (20) compressor.

\section{Future prospects}

Integrated biodiesel production system, which incorporates an enzymatic reactor and $\mathrm{SC}-\mathrm{CO}_{2}$, has rapidly gaining pace in recent years. The combination of an oil extraction unit with the enzymatic reactor is a promising platform to reduce energy consumption and operating cost in biodiesel production. This exciting yet challenging technology endeavor however seeks further affirmation before it can finally be realized at a commercial scale.

Monolithic reactor has shown a great potential for enzymatic-based reaction in $\mathrm{SC}-\mathrm{CO}_{2}$ system due to its durability in high temperature and pressure applications. The pore size can easily be tailored for large and viscous biomolecules such as triglycerides thus eliminating the issues of pressure build-up especially during a high-throughput process. The pressure drop in monoliths is significantly lower than conventional supports at a given flow rate due to its largely interconnected pore and convective mass transport properties. These features allow monoliths to be applied as an industrial-scale biodiesel reactor where time and volume are two major factors contributing to its economic feasibility.

Co-immobilization of multiple enzymes on a monolith surface is another promising approach that may facilitate an enhanced reaction in a single reactor. Transesterification of lipids involves several steps where acyl migration is the rate-determining factor. Lee et al. (2011) have shown that the combination of Rhizopus oryzae lipase (ROL) and C. rugosa lipase (CRL) in a SC- $\mathrm{CO}_{2}$ process could eliminate the acyl-migration step. Although coimmobilization of enzymes on monoliths shows promising results, the feasibility of the technique at a commercial scale remains questionable.

Surface modification such as the addition of chemicals to generate functional groups may have detrimental effects on the native structure of the enzyme. As the enzyme conformation may change upon immobilization, strategies on how to improve immobilization efficiency still remain as a research endeavor. Hanefeld et al. (2009) demonstrated an oriented immobilization of $T$. lanuginosus lipase through the removal of lysine residues near the active site thus promoting greater substrateenzyme interfacial reactions as depicted in Figure 9. Lozano et al. (2004) revealed an optimum microenvironment for the synthesis of short chain alkyl esters in SC- $\mathrm{CO}_{2}$ system by coating $C$. antartica lipase B with ILs and obtained an increased free energy of deactivation to $25 \mathrm{~kJ} / \mathrm{mol}$ and improved half-time by 2000 -folds.

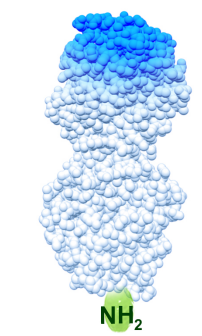

Modified enzyme with only one lysine residue on surface

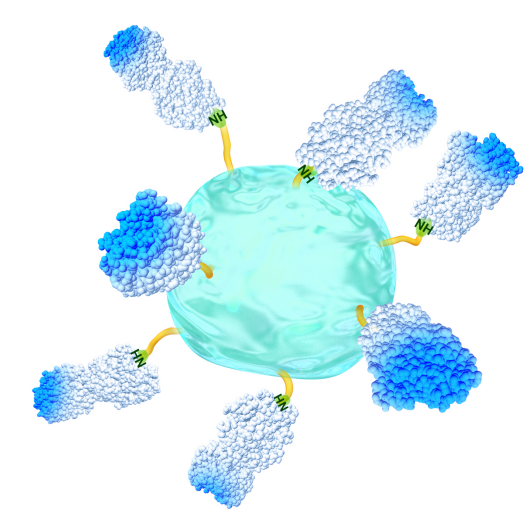

Fig.9. Modified enzyme with just one amino group on its surface, ideally oriented when covalently immobilized (adopted from Hanefeld et al., 2009).

The inhibition effect of alcohol in a reaction medium can be minimized using a solvent-free transesterification system or a stepwise addition of alcohol (Shimada et al., 1999, 2002; Fernando and Vasudevan, 2006; Kawakami et al., 2011). The stepwise addition of alcohol has achieved a complete lipid-to-biodiesel conversion within $2 \mathrm{~h}$ as compared to $3 \mathrm{~h}$ by bulk addition of alcohol with an increased reusability of up to 20 cycles (Lee et al., 2011).

As a conclusion, the search for alternative feedstocks for green biodiesel production is still ongoing. Microalgal biomass has been proposed as the next-generation feedstocks for biodiesel mainly due to its high lipid content and high yield per acre compared to other plants with zero impact on food security. Apparently, the incorporation of monolithic enzymatic reactors, particularly in a microalgal-based biodiesel production platform, shows a highly promising economic potential. An integrated system that combines the extraction of oil from feedstock and the direct bioconversion of lipid into biodiesel using an enzymatic reactor in $\mathrm{SC}-\mathrm{CO}_{2}$ has been discussed. Although still in the infancy stage, the aforementioned technology has been demonstrated successfully, at least, in bench-top studies.

\section{References}

[1] Altın, R., Çetinkaya, S., Yücesu, H.S., 2001. The potential of using vegetable oil fuels as fuel for diesel engines. Energy Convers. Manage. 42, 529-538.

[2] Al-Zuhair, S., Hussein, A., Al-Marzouqi, A.H., Hashim, I., 2012. Continuous production of biodiesel from fat extracted from lamb meat in supercritical $\mathrm{CO}_{2}$ media. Biochem. Eng. J. 60, 106-110.

[3] Al-Zuhair, S., Ling, F.W., Jun, L.S., 2007. Proposed kinetic mechanism of the production of biodiesel from palm oil using lipase. Process Biochem. 42, 951-960. 
[4] Ameur, S.B., Luminița Gîjiu, C., Belleville, M.P., Sanchez, J., PaolucciJeanjean, D., 2014. Development of a multichannel monolith large-scale enzymatic membrane and application in an immobilized enzymatic membrane reactor. J. Membr. Sci. 455, 330-340.

[5] Anuar, S.T., Zhao, Y.Y., Mugo, S.M., Curtis, J.M., 2013. The development of a capillary microreactor for transesterification reactions using lipase immobilized onto a silica monolith. J. Mol. Catal. B: Enzym. 92, 62-70.

[6] Aransiola, E.F., Ojumu, T.V., Oyekola, O.O., Madzimbamuto, T.F., Ikhu-Omoregbe, D.I.O., 2014. A review of current technology for biodiesel production: State of the art. Biomass Bioenergy. 61, 276-297.

[7] Aresta, M., Dibenedetto, A., Carone, M., Colonna, T., Fragale, C., 2005. Production of biodiesel from macroalgae by supercritical $\mathrm{CO}_{2}$ extraction and thermochemical liquefaction. Environ. Chem. Lett. 3(3), 136-139.

[8] Arica, M.Y., Altintas, B., Bayramoglu, G., 2009. Immobilization of laccase onto spacer-arm attached non-porous poly(GMA/EGDMA) beads: Application for textile dye degradation. Bioresour. Technol. 100(2), 665-669

[9] Arica, M.Y., Senel, S., Alaeddinoglu, N.G., Patir, S., Denizli, A., 2000. Invertase immobilized on spacer-arm attached poly (hydroxyethyl methacrylate) membrane: preparation and properties. J. Appl. Polym. Sci. 75(14), 1685-1692.

[10] Bacskay, I., Sepsey, A., Felinger, A., 2014. The pore size distribution of the first and the second generation of silica monolithic stationary phases. J. Chromatogr. A. 1359, 112-116.

[11] Badgujar, K.C., Dhake, K.P., Bhanage, B.M., 2013. Immobilization of Candida cylindracea lipase on poly lactic acid, polyvinyl alcohol and chitosan based ternary blend film: characterization, activity, stability and its application for N-acylation reactions. Process Biochem. 48(9), $1335-1347$

[12] Bai, H.X., Shen, X.Z., Liu, X.H., Liu, S.Y., 2009. Synthesis of porous $\mathrm{CaO}$ microsphere and its application in catalyzing transesterification reaction for biodiesel. Trans. Nonferrous Met. Soc. China. 19, s674s677.

[13] Bakry, R., Stöggl, W.M., Hochleitner, E.O., Stecher, G., Huck, C.W., Bonn, G.K., 2006. Silica particles encapsulated poly (styrenedivinylbenzene) monolithic stationary phases for micro-high performance liquid chromatography. J. Chromatogr. A. 1132(1-2), 183189

[14] Balcão, V.M., Paiva, A.L., Xavier Malcata, F., 1996. Bioreactors with immobilized lipases: state of the art. Enzyme Microb. Technol. 18(6), 392-416.

[15] Barbosa, O., Torres, R., Ortiz, C., Fernandez-Lafuente, R., 2012. Versatility of glutaraldehyde to immobilize lipases: effect of the immobilization protocol on the properties of lipase B from Candida antarctica. Process Biochem. 47(8), 1220-1227.

[16] Baskar, G., Aiswarya, R., 2016. Trends in catalytic production of biodiesel from various feedstocks. Renew. Sustain. Energy Rev. 57, 496 $-504$

[17] Bayramoglu, G., Kaya, B., Arica, M.Y., 2005. Immobilization of Candida rugosa lipase onto spacer-arm attached poly (GMA-HEMAEGDMA) microspheres. Food Chem. 92(2), 261-268.

[18] Bélafi-Bakó, K., Kovács, F., Gubicza, L., Hancsók, J., 2002. Enzymatic biodiesel production from sunflower oil by Candida antarctica lipase in a solvent-free system. Biocatal. Biotransform. 20(6), 437-439.

[19] Blanco, R.M., Terreros, P., Fernandez-Perez, M., Otero, C., DiazGonzalez, G., 2004. Functionalization of mesoporous silica for lipase immobilization: characterization of the support and the catalysts. J. Mol. Catal. B: Enzym. 30(2), 83-93.

[20] Borges, M.E., Diaz, L., 2012. Recent developments on heterogeneous catalysts for biodiesel production by oil esterification and transesterification reactions: a review. Renew. Sustain. Energy Rev. $16(5), 2839-2849$.

[21] Brennan, L., Owende, P., 2010. Biofuels from microalgae- a review of technologies for production, processing, and extractions of biofuels and co-products. Renew. Sust. Energy Rev. 14(2), 557-577.

[22] Cabrera, K., 2004. Applications of silica-based monolithic HPLC columns. J. Sep. Sci. 27(10-11), 843-852.

[23] Canakci, M., Van Gerpen, J. 1999. Biodiesel production via acid catalysis. Trans. ASAE (American Soc. Agric). Eng. 42(5), 1203-1210.
[24] Cannilla, C., Bonura, G., Rombi, E., Arena, F., Frusteri, F., 2010 Highly effective $\mathrm{MnCeO}_{x}$ catalysts for biodiesel production by transesterification of vegetable oils with methanol. Appl. Catal., A 382(2), 158-166

[25] Cao, L., van Langen, L., Sheldon, R.A., 2003. Immobilised enzymes: Carrier-bound or carrier-free?. Curr. Opin. Biotechnol. 14(4), 387-394.

[26] Čerče, T., Peter, S., Weidner, E., 2005. Biodiesel-transesterification of biological oils with liquid catalysts: thermodynamic properties of oil -methanol -amine mixtures. Ind. Eng. Chem. Res. 44, 9535-9541.

[27] Chen, C.H., Chen, W.H., Chang, C.M.J., Lai, S.M., Tu, C.H., 2010a Biodiesel production from supercritical carbon dioxide extracted Jatropha oil using subcritical hydrolysis and supercritical methylation. J. Supercrit. Fluids. 52(2), 228-234.

[28] Chen, W.H., Chen, C.H., Chang, C.M.J., Liau, B.C., Hsiang, D., 2010b. Supercritical carbon dioxide extraction of triglycerides from Aquilaria crassna seeds. Sep. Purif. Technol. 73(2), 135-141.

[29] Chen, X., Tolley, H.D., Lee, M.L., 2009. Polymeric strong cation-exchange monolithic column for capillary liquic chromatography of peptides and proteins. J. Sep. Sci. 32(15-16), 2565-2573.

[30] Cheng, J.J., Timilsina, G.R., 2011. Status and barriers of advanced biofuel technologies: a review. Renew. Energ. 36(12), 3541-3549.

[31] Chisti, Y., 2007. Biodiesel from microalgae. Biotechnol. Adv. 25 , 294-306.

[32] Chouhan, A.P.S., Sarma, A.K., 2011. Modern heterogeneous catalysts for biodiesel production: a comprehensive review. Renew. Sust. Energy Rev. 15(9), 4378-4399.

[33] Christopher, L.P., Zambare, V.P., 2014. Enzymatic biodiesel challenges and opportunities. Appl. Energy 119, 497-520.

[34] Ciftci, O.N., Temelli, F., 2011. Continuous production of fatty acid methyl esters from corn oil in a supercritical carbon dioxide bioreactor. J. Supercrit. Fluids. 58(1), 79-87.

[35] Crookes, R.J., 2006. Comparative bio-fuel performance in internal combustion engines. Biomass Bioenergy. 30(5), 461-468.

[36] Datta, S., Christena, L.R., Rajaram, Y.R.S., 2012. Enzyme immobilization: an overview on techniques and support materials. 3 Biotech. 3(1), 1-9.

[37] Demirbas, A., 2009. Progress and recent trends in biodiesel fuels. Energy Convers. Manag. 50(1), 14-34.

[38] Demirbas, A., 2005. Biodiesel production from vegetable oils via catalytic and non-catalytic supercritical methanol transesterification methods. Prog. Energy Combust. Sci. 31(5-6), 466-487.

[39] Dizge, N., Aydiner, C., Imer, D.Y., Bayramoglu, M., Tanriseven, A., Keskinler, B., 2009a. Biodiesel production from sunflower, soybean, and waste cooking oils by transesterification using lipase immobilized onto a novel microporous polymer. Bioresour. Technol 100(6), 1983-1991

[40] Dizge, N., Keskinler, B., Tanriseven, A., 2009b. Biodiesel production from canola oil by using lipase immobilized onto hydrophobic microporous styrene-divinylbenzene copolymer. Biochem. Eng. J. 44(2-3), 220-225.

[41] Dizge, N., Keskinler, B., 2008. Enzymatic production of biodiese from canola oil using immobilized lipase. Biomass Bioenergy. 32(12), 1274-1278.

[42] Dizge, N., Keskinler, B., Tanriseven, A., 2008. Covalent attachment of microbial lipase onto microporous styrene-divinylbenzene copolymer by means of polyglutaraldehyde. Colloids Surf. B. 66(1), 34-38.

[43] Du, W., Li, W., Sun, T., Chen, X., Liu, D., 2008. Perspectives for biotechnological production of biodiesel and impacts. Appl Microbiol. Biotechnol. 79, 331-337

[44] Du, W., Xu, Y., Liu, D., Zeng, J., 2004. Comparative study on lipase-catalyzed transformation of soybean oil for biodiesel production with different acyl acceptors. J. Mol. Catal. B: Enzym. 30(3-4), 125-129.

[45] Du, W., Xu, Y.Y., Liu, D.H., Li, Z.B., 2005. Study on acy migration in immobilized lipozyme TL-catalyzed transesterification of soybean oil for biodiesel production. J. Mol. Catal. B: Enzym. $37(1-6), 68-71$ 
[46] Dulay, M.T. Kulkarni, R.P., Zare, R.N., 1998. Preparation and characterization of monolithic porous capillary columns loaded with chromatographic particles. Anal. Chem. 70(23), 5103-5107.

[47] Eeltink, S., Geiser, L., Svec, F., Fréchet, J.M.J., 2007. Optimization of the porous structure and polarity of polymethacrylate-based monolithe capillary columns for the LC-MS separation of enzymatic digests. J. Sep. Sci. 30(17), 2814-2820.

[48] Endalew, A.K., Kiros, Y., Zanzi, R., 2011. Heterogeneous catalysis for biodiesel production from Jatropha curcas oil (JCO). Energy. 36(5), 2693-2700

[49] Fernando, S., Vasudevan, P.T., 2006. Enzyme catalyzed production of biodiesel from olive oil. Appl. Biochem. Biotechnol. 135(1), 1-14

[50] Fields, S.M., 1996. Silica xerogel as a continuous column support for high-performance liquid chromatography. Anal. Chem. 68(15), 27092712.

[51] Fjerbaek, L., Christensen, K.V., Norddahl, B., 2009. A review of the current state of biodiesel production using enzymatic transesterification. Biotechnol. Bioeng. 102(5), 1298-1315.

[52] Fukuda, H., Kondo, A., Noda, H., 2001. Biodiesel fuel production by transesterification of oils. J. Biosci. Bioeng. 92(5), 405-416.

[53] Gao, Y., Skutsch, M., Masera, O., Pacheco, P., 2011. A global analysis of deforestation due to biofuel development, Center for international forestry research, CIFOR working paper.

[54] Gao, Y., Tan, T., Nie, K., Wang, F., 2006. Immobilization of lipase on macroporous resin and its application in synthesis of biodiesel in low aqueous media. Chin. J. Biotechnol. 22(1), 114-118.

[55] Ghaly, A.E., Dave, D., Brooks, M.S., Budge, S., 2010. Production of biodiesel by enzymatic transesterification: review. Am. J. Biochem. Biotechnol. 6(2), 54-76.

[56] Gitlesen, T., Bauer, M., Adlercreutz, P., 1997. Adsorption of lipase on polypropylene powder. Biochim. Biophys. Acta, Lipids Lipid Metab. $1345(2), 188-196$.

[57] Guillarme, D., Ruta, J., Rudaz, S., Veuthey, J.L., 2010. New trends in fast and high-resolution liquid chromatography: a critical comparison of existing approaches. Anal. Bioanal. Chem. 397(3), 1069-1082.

[58] Gusev, I., Huang, X., Horváth, C., 1999. Capillary columns with in situ formed porous monolithic packing for micro high-performance liquid chromatography and capillary electrochromatography. J. Chromatogr. A. 855(1), 273-290

[59] Hama, S., Yamaji, H., Fukumizu, T., Numata, T., Tamalampudi, S., Kondo, A., Noda, H., Fukuda, H., 2007. Biodiesel-fuel production in a packed-bed reactor using lipase-producing Rhizopus oryzae cells immobilized within biomass support particles. Biochem. Eng. J. 34(3), 273-278.

[60] Hanefeld, U., Gardossi, L., Magner, E., 2009. Understanding enzyme immobilisation. Chem. Soc. Rev. 38(2), 453-468.

[61] He, P., Greenway, G., Haswell, S.J., 2009. Development of enzyme immobilized monolith micro-reactors integrated with microfluidic electrochemical cell for the evaluation of enzyme kinetics. Microfluid. Nanofluid. 8(5), 565-573

[62] Helwani, Z., Othman, M.R., Aziz, N., Fernando, W.J.N., Kim, J., 2009. Technologies for production of biodiesel focusing on green catalytic techniques: a review. Fuel Process. Technol. 90(12), 1502-1514.

[63] Hilal, N., Nigmatullin, R., Alpatova, A., 2004. Immobilization of crosslinked lipase aggregates within microporous polymeric membranes. J. Membr. Sci. 238(1-2), 131-141.

[64] Hjertén, S., Liao, J.L., Zhang, R., 1989. High-performance liquid chromatography on continuous polymer beds. J. Chromatogr. A. 473, 273-275.

[65] Huang, X.J., Yu, A.G., Xu, Z.K., 2008. Covalent immobilization of lipase from Candida rugosa onto poly (acrylonitrile-co-2-hydroxyethyl methacrylate) electrospun fibrous membranes for potential bioreactor application. Bioresour. Technol. 99(13), 5459-5465.

[66] Husain, Q., Ahmed, S., Alam, F., Azam, A., 2011. International journal of biological macromolecules immobilization of Aspergillus oryzae $\beta$ galactosidase on zinc oxide nanoparticles via simple adsorption mechanism. Int. J. Biol. Macromol. 49(1), 37-43.

[67] Imahara, H., Minami, E., Hari, S., Saka, S., 2008. Thermal stability of biodiesel in supercritical methanol. Fuel. 87(1-6), 1-6.
[68] Jegannathan, K.R., Abang, S., Poncelet, D., Chan, E.S., Ravindra, P., 2008. Production of biodiesel using immobilized lipase - a critical review. Crit. Rev. Biotechnol. 28(4), 253-264.

[69] Jesionowski, T., Zdarta, J., Krajewska, B., 2014. Enzyme immobilization by adsorption: a review. Adsorption. 20(5), 801-821.

[70] Jiang, Y., Shi, L., Huang, Y., Gao, J., Zhang, X., Zhou, L., 2014. Preparation of robust biocatalyst based on cross-linked enzyme aggregates entrapped in three-dimensionally ordered macroporous silica. ACS Appl. Mater. Interfaces. 6(4), 2622-2628.

[71] Jitputti, J., Kitiyanan, B., Rangsunvigit, P., Bunyakiat, K., Attanatho, L., Jenvanitpanjakul, P., 2006. Transesterification of crude palm kernel oil and crude coconut oil by different solid catalysts. Chem. Eng. J. 116(1), 61-66.

[72] Kashani, N., Siegert, M., Sirch, T., 2005. A new kind of column packing for conventional and reactive distillation - the sandwich packing. Chem. Eng. Technol. 28(5), 549-552.

[73] Kato, M., Sakai-Kato, K., Toyo'oka, T., 2005. Silica sol-gel monolithic materials and their use in a variety of applications. J. Sep. Sci. 28(15), 1893-1908.

[74] Kawakami, K., Abe, D., Urakawa, T., Kawashima, A., Oda, Y. Takahashi, R., Sakai, S., 2007. Development of a silica monolith microbioreactor entrapping highly activated lipase and an experiment toward integration with chromatographic separation of chiral esters. J. Sep. Sci. 30(17), 3077-3084.

[75] Kawakami, K., Oda, Y., Takahashi, R., 2011. Application of a Burkholderia cepacia lipase-immobilized silica monolith to batch and continuous biodiesel production with a stoichiometric mixture of methanol and crude Jatropha oil. Biotechnol. Biofuels. 4(1), 42.

[76] Kawakami, K., Takahashi, R., Shakeri, M., Sakai, S., 2009 Application of a lipase-immobilized silica monolith bioreactor to the production of fatty acid methyl esters. J. Mol. Catal. B: Enzym. 57(1-4), 194-197.

[77] Kawakami, K., Ueno, M., Takei, T., Oda, Y., Takahashi, R., 2012. Application of a Burkholderia cepacia lipase-immobilized silica monolith micro-bioreactor to continuous-flow kinetic resolution for transesterification of $(R, S)$-1-phenylethanol. Process Biochem. 47(1), 147-150.

[78] Kim, H.J., Kang, B.S., Kim, M.J., Park, Y.M., Kim, D.K., Lee, J.S Lee, K.Y., 2004. Transesterification of vegetable oil to biodiesel using heterogeneous base catalyst. Catal. Today. 93-95, 315-320.

[79] Knezevic, Z., Milosavic, N., Bezbradica, D., Jakovljevic, Z., Prodanovic, R., 2006. Immobilization of lipase from Candida rugosa on Eupergit ${ }^{\circledR}$ C supports by covalent attachment. Biochem. Eng. J. 30(3), 269-278

[80] Knothe, G., 2008. "Designer" Biodiesel: Optimizing Fatty Ester Composition to Improve Fuel Properties. Energy Fuels. 22(2), 1358-1364.

[81] Kondamudi, N., Mohapatra, S.K., Misra, M., 2011. Quintinite as a bifunctional heterogeneous catalyst for biodiesel synthesis. Appl. Catal., A. 393(1-2), 36-43

[82] Kondoh, E., Fukuda, J., 2008. Deposition kinetics and narrow-gapfilling in $\mathrm{Cu}$ thin film growth from supercritical carbon dioxide fluids. J. Supercrit. Fluids. 44(3), 466-474.

[83] Křenková, J., Foret, F., 2004. Immobilized microfluidic enzymatic reactors. Electrophoresis. 25(21-22), 3550-3563.

[84] Krishna, R., Sie, S.T., 1994. Strategies for multiphase reactor selection. Chem. Eng. Sci. 49(24), 4029-4065.

[85] Kumari, V., Shah, S., Gupta, M.N., 2007. Preparation of biodiesel by lipase-catalyzed transesterification of high free fatty acic containing oil from Madhuca indica. Energy Fuels. 21(1), 368-372.

[86] Lai, J.Q., Hu, Z.L., Sheldon, R. A., Yang, Z., 2012. Catalytic performance of cross-linked enzyme aggregates of Penicillium expansum lipase and their use as catalyst for biodiesel production. Process Biochem. 47(12), 2058-2063.

[87] Lalonde, J., Margolin, A., 2008. Immobilization of enzymes, in Drauz, K., Waldmann, H. (Eds.), Enzyme catalysis in organic chemistry. Wiley-VCH, Weinheim, pp. 163-184.

[88] Lam, M.K., Lee, K.T., Mohamed, A.R., 2010. Homogeneous, heterogeneous and enzymatic catalysis for transesterification of high 
free fatty acid oil (waste cooking oil) to biodiesel: a review. Biotechnol. Adv. 28(4), 500-518.

[89] Lanza, M., Priamo, W.L., Oliveira, J.V., Dariva, C., de Oliveira, D., 2004. The effect of temperature, pressure, exposure time, and depressurization rate on lipase activity in $\mathrm{SCCO}_{2}$. Appl. Biochem. Biotechnol. 113(1), 181-187.

[90] Lauren, B., Rein, V.U., Peter, J.H., 2013. Effect of pore size on the performance of immobilised enzymes. Chem. Soc. Rev. 42(23), $9000-$ 9010

[91] Lee, J.H., Kim, S.B., Kang, S.W., Song, Y.S., Park, C., Han, S.O., Kim, S.W., 2011. Biodiesel production by a mixture of Candida rugosa and Rhizopus oryzae lipases using a supercritical carbon dioxide process. Bioresour. Technol. 102(2), 2105-2108.

[92] Lee, J.S., Saka, S., 2010. Biodiesel production by heterogeneous catalysts and supercritical technologies. Bioresour. Technol. 101(19), 7191-7200

[93] Leung, D.Y.C., Wu, X., Leung, M.K.H., 2010. A review on biodiesel production using catalyzed transesterification. Appl. Energy. 87(4), 1083-1095.

[94] Li, L., Du, W., Liu, D., Wang, L., Li, Z., 2006. Lipase-catalyzed transesterification of rapeseed oils for biodiesel production with a novel organic solvent as the reaction medium. J. Mol. Catal. B: Enzym. 43(14), 58-62.

[95] Li, W., Du, W., Liu, D., 2007. Rhizopus oryzae IFO 4697 whole cell catalyzed methanolysis of crude and acidified rapeseed oils for biodiesel production in tert-butanol system. Process Biochem. 42(11), 1481-1485.

[96] Li, Y., Horsman, M., Wu, N., Lan, C.Q., Dubois-calero, N., 2008. Biofuels from Microalgae. Biotechnol. Progr. 24(4), 815-820.

[97] Liu, J., Chen, C.F., Tsao, C.W., Chang, C.C., Chu, C.C., DeVoe, D.L., 2009. Polymer microchips integrating solid-phase extraction and highperformance liquid chromatography using reversed-phase polymethacrylate monoliths. Anal. Chem. 81(7), 2545-2554.

[98] Liu, J., White, I., DeVoe, D.L., 2011. Nanoparticle-functionalized porous polymer monolith detection elements for surface-enhanced raman scattering. Anal. Chem. 83(6), 2119-2124.

[99] Lozano, P., Bernal, J.M., Vaultier, M., 2011. Towards continuous sustainable processes for enzymatic synthesis of biodiesel in hydrophobic ionic liquids/supercritical carbon dioxide biphasic systems. Fuel. 90(11), 3461-3467

[100]Lozano, P., De Diego, T., Gmouh, S., Vaultier, M., Iborra, J.L., 2004. Criteria to design green enzymatic processes in ionic liquid/ supercritical carbon dioxide systems. Biotechnol. Prog. 20(3),661-669.

[101]Lozano, P., García-Verdugo, E., Piamtongkam, R., Karbass, N., De Diego, T., Burguete, M.I., Luis, S.V., Iborra, J.L., 2007. Bioreactors based on monolith-supported ionic liquid phase for enzyme catalysis in supercritical carbon dioxide. Adv. Synth. Catal. 349(7), 1077-1084.

[102]Lu, J., Nie, K., Wang, F., Tan, T., 2008. Immobilized lipase Candida sp. 99-125 catalyzed methanolysis of glycerol trioleate: solvent effect. Bioresour. Technol. 99(14), 6070-6074.

[103]Lu, J., Nie, K., Xie, F., Wang, F., Tan, T., 2007. Enzymatic synthesis of fatty acid methyl esters from lard with immobilized Candida sp. 99-125. Process Biochem. 42(9), 1367-1370.

[104]Luangon, B., Siyasukh, A., Winayanuwattikun, P., Tanthapanichakoon, W., 2012. Flow-through immobilization of Candida rugosa lipase on hierarchical micro- / macroporous carbon monolith. J. Mol. Catal. B: Enzym. 75, 80-85.

[105]Lv, Y., Lin, Z., Tan, T., Svec, F., 2014. Preparation of reusable bioreactors using reversible immobilization of enzyme on monolithic porous polymer support with attached gold nanoparticles. Biotechnol. Bioeng. 111(1), 50-58.

[106]Ma, F., Clements, L.D., Hanna, M.A., 1998. Biodiesel fuel from animal fat. Ancillary studies on transesterification of beef tallow. Ind. Eng. Chem. Res. 37(9), 3768-3771.

[107]Ma, F., Hanna, M.A., 1999. Biodiesel production: a review. Bioresour. Technol. 70(1), 1-15.

[108]Macario, A., Giordano, G., Onida, B., Cocina, D., Tagarelli, A., Giuffrè, A.M., 2010. Biodiesel production process by homogeneous/heterogeneous catalytic system using an acid-base catalyst. Appl. Catal., A. 378(2), 160-168.
[109] Marchetti, J.M., Miguel, V.U., Errazu, A.F., 2007. Possible methods for biodiesel production. Renew. Sustain. Energy Rev. 11(6), 13001311.

[110]Mateo, C., Torres, R., Fernández-Lorente, G., Ortiz, C., Fuentes, M., Hidalgo, A., López-Gallego, F., Abian, O., Palomo, J.M., Betancor, L., Pessela, B.C.C., Guisan, J.M., Fernández-Lafuente, R., 2003. Epoxy-amino groups: a new tool for improved immobilization of proteins by the epoxy method. Biomacromolecules. 4(3), 772-777.

[111]Math, M.C., Kumar, S.P., Chetty, S. V., 2010. Technologies for biodiesel production from used cooking oil - a review. Energy Sustain. Dev. 14(4), 339-345.

[112]Matsuda, T., Harada, T., Nakamura, K., 2004. Organic synthesis using enzymes in supercritical carbon dioxide. Green Chem. 6(9), 440-444.

[113]Meador, M.A.B., Fabrizio, E.F., Ilhan, F., Dass, A., Zhang, G., Vassilaras, P., Johnston, J.C., Leventis, N., 2005. Cross-linking amine-modified silica aerogels with epoxies: mechanically strong lightweight porous materials. Chem. Mater. 17(5), 1085-1098.

[114]Melero, J.A., Iglesias, J., Morales, G., 2009. Heterogeneous acid catalysts for biodiesel production: current status and future challenges. Green Chem. 11(9), 1285-1308.

[115] Mendes, A.A., Giordano, R.C., Giordano, R.D.L.C., de Castro, H.F. 2011. Immobilization and stabilization of microbial lipases by multipoint covalent attachment on aldehyde-resin affinity: application of the biocatalysts in biodiesel synthesis. J. Mol. Catal. B: Enzym. 68(1), 109-115.

[116]Milosavić, N., Prodanović, R., Jovanović, S., Vujčić, Z., 2007. Immobilization of glucoamylase via its carbohydrate moiety on macroporous poly(GMA-co-EGDMA). Enzyme Microb. Technol. 40(5), 1422-1426.

[117]Minami, E., Saka, S., 2006. Kinetics of hydrolysis and methyl esterification for biodiesel production in two-step supercritical methanol process. Fuel. 85(17), 2479-2483.

[118]Misson, M., Du, X., Jina, B., Zhanga, H., 2016. Dendrimer-like nanoparticles based $\beta$-galactosidase assembly for enhancing its selectivity towards transgalactosylation. Enzyme Microbial. Technol. 84, 68-77.

[119]Misson, M., Jin, B., Chen, B., Zhang, H., 2015a. Enhancing enzyme stability and metabolic functional ability of $\mathrm{b}$-galactosidase through functionalized polymer nanofiber immobilization. Bioprocess Biosyst. Eng. 38, 1915-1923.

[120]Misson, M., Zhang, H., Jin, B., 2015b. Nanobiocatalyst advancements and bioprocessing applications. J. R. Soc. Interface 12(102), 20140891.

[121]Modi, M.K., Reddy, J.R.C., Rao, B.V.S.K., Prasad, R.B.N., 2006 Lipase-mediated transformation of vegetable oils into biodiese using propan-2-ol as acyl acceptor. Biotechnol. Lett. 28(9),637-640.

[122]Motokawa, M., Ohira, M., Minakuchi, H., Nakanishi, K., Tanaka, N., 2006. Performance of octadecylsilylated monolithic silica capillary columns of $530 \mu \mathrm{m}$ inner diameter in HPLC. J. Sep. Sci. 29(16), 2471-2477.

[123]Nakanishi, K., Shikata, H., Ishizuka, N., Koheiya, N., Soga, N., 2000. Tailoring mesopores in monolithic macroporous silica for HPLC. J. Sep. Sci. 23(1), 106-110.

[124]Nakanishi, K., Soga, N., 1992. Phase separation in silica sol-ge system containing polyacrylic acid I. Gel formaation behavior and effect of solvent composition. J. Non. Cryst. Solids. 139, 1-13.

[125]Nakanishi, K., Soga, N., 1991. Phase separation in gelling silicaorganic polymer solution: systems containing Poly(sodium styrenesulfonate). J. Am. Ceram. Soc. 74(10), 2518-2530

[126]Nigam, S., Mehrotra, S., Vani, B., Rajesh, M., 2014. Lipase immobilization techniques for biodiesel production: an overview. Int. J. Renew. Energy Biofuels.1-16.

[127]Niza, N.M., Tan, K.T., Lee, K.T., Ahmad, Z., 2013. Influence of impurities on biodiesel production from Jatropha curcas L. by supercritical methyl acetate process. J. Supercrit. Fluids. 79, 73-75.

[128]Noraini, M.Y., Ong, H.C., Badrul, M.J., Chong, W.T., 2014. A review on potential enzymatic reaction for biofuel production from algae. Renew. Sust. Energy Rev. 39, 24-34. 
[129] Noureddini, H., Gao, X., Philkana, R.S., 2005. Immobilized Pseudomonas cepacia lipase for biodiesel fuel production from soybean oil. Bioresour. Technol. 96(7), 769-777.

[130] Noureddini, H., Zhu, D., 1997. Kinetics of transesterification of soybean oil. J. Am. Oil Chem. Soc. 74(11), 1457-1463.

[131]Nwagu, T.N., Okolo, B., Aoyagi, H., Yoshida, S., 2013. Improved yield and stability of amylase by multipoint covalent binding on polyglutaraldehyde activated chitosan beads: activation of denatured enzyme molecules by calcium ions. Process Biochem. 48(7), 10311038

[132]Oda, M., Kaieda, M., Hama, S., Yamaji, H., Kondo, A., Izumoto, E., Fukuda, H., 2005. Facilitatory effect of immobilized lipase-producing Rhizopus oryzae cells on acyl migration in biodiesel-fuel production. Biochem. Eng. J. 23(1), 45-51.

[133] Ognjanovic, N., Bezbradica, D., Knezevic-Jugovic, Z., 2009. Enzymatic conversion of sunflower oil to biodiesel in a solvent-free system: process optimization and the immobilized system stability. Bioresour. Technol. 100(21), 5146-5154.

[134]Ong, H.C., Mahlia, T.M.I., Masjuki, H.H., Norhasyima, R.S., 2011. Comparison of palm oil, Jatropha curcas and Calophyllum inophyllum for biodiesel: a review. Renew. Sust. Energy Rev. 15(8), 3501-3515.

[135] Ongkudon, C.M., Kansil, T., Wong, C., 2014. Challenges and strategies in the preparation of large-volume polymer-based monolithic chromatography adsorbents. J. Sep. Sci. 37(5), 455-464.

[136] Orçaire, O., Buisson, P., Pierre, A.C., 2006. Application of silica aerogel encapsulated lipases in the synthesis of biodiesel by transesterification reactions. J. Mol. Catal. B: Enzym. 42(3), 106-113.

[137]Ozyilmaz, G., 2009. The effect of spacer arm on hydrolytic and synthetic activity of Candida rugosa lipase immobilized on silica gel. J. Mol. Catal. B: Enzym. 56(4), 231-236.

[138]Palomo, J.M., Muoz, G., Fernandez-Lorente, G., Mateo, C., FernandezLafuente, R., Guisan, J.M., 2002. Interfacial adsorption of lipases on very hydrophobic support (octadecyl-Sepabeads): immobilization, hyperactivation and stabilization of the open form of lipases. J. Mol. Catal. B: Enzym. 19-20, 279-286.

[139]Pangarkar, K., Schildhauer, T.J., van Ommen, J.R., Nijenhuis, J., Moulijn, J.A., Kapteijn, F., 2009. Experimental and numerical comparison of structured packings with a randomly packed bed reactor for Fischer-Tropsch synthesis. Catal. Today. 147, S2-S9.

[140]Parawira, W., 2009. Biotechnological production of biodiesel fuel using biocatalysed transesterification: a review. Crit. Rev. Biotechnol. 29(2), 82-93.

[141]Park, C.B., Clark, D.S., 2002. Sol-gel encapsulated enzyme arrays for high-throughput screening of biocatalytic activity. Biotechnol. Bioeng. 78(2), 229-235

[142]Park, E.Y., Sato, M., Kojima, S., 2008. Lipase-catalyzed biodiesel production from waste activated bleaching earth as raw material in a pilot plant. Bioresour. Technol. 99(8), 3130-3135.

[143]Peterson, D.S., Rohr, T., Svec, F., Fréchet, J.M.J., 2002. Enzymatic microreactor-on-a-chip: protein mapping using trypsin immobilized on porous polymer monoliths molded in channels of microfluidic devices. Anal. Chem. 74(16), 4081-4088.

[144] Prodanović, R., Jovanović, S., Vujčić, Z., 2001. Immobilization of invertase on a new type of macroporous glycidyl methacrylate. Biotechnol. Lett. 23(14), 1171-1174.

[145]Raita, M., Laothanachareon, T., Champreda, V., Laosiripojana, N., 2011. Biocatalytic esterification of palm oil fatty acids for biodiesel production using glycine-based cross-linked protein coated microcrystalline lipase. J. Mol. Catal. B: Enzym. 73(1-4), 74-79.

[146] Rakopoulos, C.D., Antonopoulos, K.A., Rakopoulos, D.C., Hountalas, D.T., Giakoumis, E.G., 2006. Comparative performance and emissions study of a direct injection diesel engine using blends of diesel fuel with vegetable oils or bio-diesels of various origins. Energy Convers. Manage. 47(18-19), 3272-3287.

[147]Ramani, K., Karthikeyan, S., Boopathy, R., Kennedy, L.J., Mandal, A.B., Sekaran, G., 2012. Surface functionalized mesoporous activated carbon for the immobilization of acidic lipase and their application to hydrolysis of waste cooked oil: isotherm and kinetic studies. Process Biochem. 47(3), 435-445.
[148]Ramos, M.J., Fernández, C.M., Casas, A., Rodríguez, L., Pérez, A., 2009. Influence of fatty acid composition of raw materials on biodiesel properties. Bioresour. Technol. 100(1), 261-268.

[149]Ranganathan, S.V., Narasimhan, S.L., Muthukumar, K., 2008. An overview of enzymatic production of biodiesel. Bioresour. Technol. 99(10), 3975-3981

[150]Reetz, M.T., Zonta, A., Simpelkamp, J., Rufinska, A., Tesche, B., 1996. Characterization of hydrophobic sol-gel materials containing entrapped lipases. J. Sol-Gel Sci. Technol. 7(1), 35-43.

[151]Reverchon, E., De Marco, I., 2006. Supercritical fluid extraction and fractionation of natural matter. J. Supercrit. Fluids. 38(2), 146-166.

[152]Rodrigues, A.R., Paiva, A., Da Silva, M.G., Simões, P., Barreiros, S., 2011. Continuous enzymatic production of biodiesel from virgin and waste sunflower oil in supercritical carbon dioxide. J. Supercrit. Fluids. 56(3), 259-264

[153] Rodrigues, D.S., Mendes, A.A., Adriano, W.S., Gonçalves, L.R.B. Giordano, R.L.C., 2008. Multipoint covalent immobilization of microbial lipase on chitosan and agarose activated by different methods. J. Mol. Catal. B: Enzym. 51(3-4), 100-109.

[154]Rodrigues, R.C., Ortiz, C., Berenguer-Murcia, Á., Torres, R. Fernández-Lafuente, R., 2013. Modifying enzyme activity and selectivity by immobilization. Chem. Soc. Rev. 42(15), 6290-6307.

[155]Rodrigues, R.C., Pessela, B.C.C., Volpato, G., Fernandez-Lafuente, R., Guisan, J.M., Ayub, M.A.Z., 2010. Two step ethanolysis: a simple and efficient way to improve the enzymatic biodiesel synthesis catalyzed by an immobilized-stabilized lipase from Thermomyces lanuginosus. Process Biochem. 45(8), 1268-1273.

[156]Roy, S., Bauer, T., Al-Dahhan, M., Lehner, P., Turek, T., 2004 Monoliths as multiphase reactors: a review. AIChE J. 50(11), 2918 2938

[157]Royon, D., Daz, M., Ellenrieder, G., Locatelli, S., 2007. Enzymatic production of biodiesel from cotton seed oil using t-butanol as a solvent. Bioresour. Technol. 98(3), 648-653.

[158]Saka, S., Kusdiana, D., 2001. Biodiesel fuel from rapeseed oil as prepared in supercritical methanol. Fuel. 80(2), 225-231.

[159]Sakai, S., Liu, Y., Yamaguchi, T., 2010. Immobilization of Pseudomonas cepacia lipase onto electrospun polyacrylonitrile fibers through physical adsorption and application to transesterification in nonaqueous solvent. Biotechnol. Lett. 32, $1059-1062$

[160] Salinas, D., Guerrero, S., Araya, P., 2010. Transesterification of canola oil on potassium-supported $\mathrm{TiO}_{2}$ catalysts. Catal. Commun. 11(8), 773-777.

[161]Salis, A., Sanjust, E., Solinas, V., Monduzzi, M., 2003 Characterisation of Accurel MP1004 polypropylene powder and its use as a support for lipase immobilisation. J. Mol. Catal. B: Enzym. $24-25,75-82$.

[162] Sani, Y.M, Wan Daud, W.M.A., Abdul Aziz, A.R., 2013. Solid acidcatalyzed biodiesel production from microalgal oil-The dua advantage. J. Environ. Chem. Eng. 1(3), 113-121.

[163] Santana, A., Jesus, S., Larrayoz, M.A., Filho, R.M., 2012 Supercritical carbon dioxide extraction of algal lipids for the biodiesel production. Procedia Eng. 42, 1755-1761.

[164]Santos, H., Costa, M., 2009. Modelling transport phenomena and chemical reactions in automotive three-way catalytic converters Chem. Eng. J. 148(1), 173-183.

[165]Schenk, P.M., Thomas-Hall, S.R., Stephens, E., Marx, U.C. Mussgnug, J.H., Posten, C., Kruse, O., Hankamer, B., 2008. Second generation biofuels: high-efficiency microalgae for biodiesel production. Bioenergy Res. 1(1), 20-43.

[166]Schnepf, R., Yacobucci, B.D., 2010. Renewable fuel standard (RFS): overview and issues, CRS Report No. R40155 for U.S Congress, Congressional Research Service (CRS), p. 29.

[167] Šefčik, J., McCormick, A.V., 1997. Kinetic and thermodynamic issues in the early stages of sol-gel processes using silicon alkoxides. Catal. Today. 35(3), 205-223.

[168] Shah, S., Gupta, M.N., 2007. Lipase catalyzed preparation of biodiesel from Jatropha oil in a solvent free system. Process Biochem. 42(3), 409-414. 
[169] Shah, S., Sharma, S., Gupta, M.N., 2004. Biodiesel preparation by lipase-catalyzed transesterification of Jatropha oil. Energy Fuels. 18(1), 154-159.

[170] Shakeri, M., Kawakami, K., 2008. Effect of the structural chemical composition of mesoporous materials on the adsorption and activation of the Rhizopus oryzae lipase-catalyzed trans-esterification reaction in organic solvent. Catal. Commun. 10(2), 165-168.

[171]Shao, P., Meng, X., He, J., Sun, P., 2008. Analysis of immobilized Candida rugosa lipase catalyzed preparation of biodiesel from rapeseed soapstock. Food Bioprod. Process. 86(4), 283-289.

[172]Sheehan, J., Camobreco, V., Duffield, J., Shapouri, H., Graboski, M., Tyson, K.S., 2000. An overview of biodiesel and petroleum diesel life cycles (No. NREL/TP-580-24772). National Renewable Energy Lab., Golden, CO (U.S.)

[173] Sheldon, R.A., 2011. Characteristic features and biotechnological applications of cross-linked enzyme aggregates (CLEAs). Appl. Microbiol. Biotechnol. 92(3), 467-477.

[174] Sheldon, R.A., 2007. Enzyme immobilization: the quest for optimum performance. Adv. Synth. Catal. 349(8-9), 1289-1307.

[175]Shi, Z.G., Feng, Y.Q., Xu, L., Zhang, M., Da, S.L., 2004. Preparation and evaluation of zirconia-coated silica monolith for capillary electrochromatography. Talanta. 63(3), 593-598

[176] Shimada, Y., Watanabe, Y., Samukawa, T., Sugihara, A., Noda, H., Fukuda, H., Tominaga, Y., 1999. Conversion of vegetable oil to biodiesel using immobilized Candida antarctica lipase. J. Am. Oil Chem. Soc. 76(7), 789-793.

[177] Shimada, Y., Watanabe, Y., Sugihara, A., Tominaga, Y., 2002. Enzymatic alcoholysis for biodiesel fuel production and application of the reaction to oil processing. J. Mol. Catal. B: Enzym. 17(3-5), 133142 .

[178] Soares, C.M.F., dos Santos, O.A., Olivo, J.E., de Castro, H.F., de Moraes, F.F., Zanin, G.M., 2004. Influence of the alkyl-substituted silane precursor on sol-gel encapsulated lipase activity. J. Mol. Catal. B: Enzym. 29(1-6), 69-79.

[179]Soh, L., Zimmerman, J., 2011. Biodiesel production: the potential of algal lipids extracted with supercritical carbon dioxide. Green Chem. 13(6), 1422-1429.

[180]Soldi, R.A., Oliveira, A.R.S., Ramos, L.P., César-Oliveira, M.A.F., 2009. Soybean oil and beef tallow alcoholysis by acid heterogeneous catalysis. Appl. Catal., A. 361(1-2), 42-48.

[181] Stachowiak, T.B., Mair, D.A., Holden, T.G., Lee, L.J., Svec, F., Fréchet, J.M.J., 2007. Hydrophilic surface modification of cyclic olefin copolymer microfluidic chips using sequential photografting. J. Sep. Sci. 30(7), 1088-1093.

[182] Stickel, J.J., Fotopoulos, A., 2001. Pressure-flow relationships for packed beds of compressible chromatography media at laboratory and production scale. Biotechnol. Prog. 17(4), 744-751.

[183] Strancar, A., Podgornik, A., Barut, M., Necina, R., 2002. Short monolithic columns as stationary phases for biochromatography. Adv. Biochem. Eng. Biotechnol. 76, 49-85.

[184]Svec, F., 2010. Porous polymer monoliths: amazingly wide variety of techniques enabling their preparation. J. Chromatogr. A 1217(6), 902924.

[185] Svec, F., Fréchet, J.M.J., 1992. Continuous rods of macroporous polymer as high-performance liquid chromatography separation media. Anal. Chem. 64(7), 820-822

[186]Taher, H., Al-Zuhair, S., Al-Marzouqi, A.H., Haik, Y., Farid, M., Tariq, S., 2014. Supercritical carbon dioxide extraction of microalgae lipid: process optimization and laboratory scale-up. J. Supercrit. Fluids. 86, $57-66$.

[187]Taher, H., Al-Zuhair, S., Al-Marzouqi, A.H., Haik, Y., Farid, M.M., 2011a. A review of enzymatic transesterification of microalgal oil-based biodiesel using supercritical technology. Enzyme Res. 2011, 1-25.

[188]Taher, H., Al-Zuhair, S., AlMarzouqui, A., Hashim, I., 2011b. Extracted fat from lamb meat by supercritical $\mathrm{CO}_{2}$ as feedstock for biodiesel production. Biochem. Eng. J. 55(1), 23-31

[189]Tan, K.T., Lee, K.T., Mohamed, A.R., 2010a. Effects of free fatty acids, water content and co-solvent on biodiesel production by supercritical methanol reaction. J. Supercrit. Fluids. 53(1-3), 88-91.
[190]Tan, K.T., Lee, K.T., Mohamed, A.R., 2009. Production of FAME by palm oil transesterification via supercritical methanol technology. Biomass Bioenergy. 33(8), 1096-1099.

[191]Tan, T., Lu, J., Nie, K., Deng, L., Wang, F., 2010b. Biodiese production with immobilized lipase: a review. Biotechnol. Adv. 28(5), 628-634.

[192]Tanaka, N., Kobayashi, H., Ishizuka, N., Minakuchi, H., Nakanishi, K., Hosoya, K., Ikegami, T., 2002. Monolithic silica columns for high-efficiency chromatographic separations. J. Chromatogr. A 965(1-2), 35-49.

[193]Tennikova, T.B., Svec, F., Belenkii, B.G., 1990. High-performance membrane chromatography. A novel method of protein separation. J. Liq. Chromatogr. 13(1), 63-70.

[194]Urban, J., Svec, F., Fréchet, J.M.J., 2012. A monolithic lipase reactor for biodiesel production by transesterification of triacylglycerides into fatty acid methyl esters. Biotechnol. Bioeng. 109(2), 371-380.

[195]U.S. Department of Energy, 2014. Clean cities alternative fuel price report.

[196] Vicente, G., Coteron, A., Martinez, M., Aracil, J., 1998. Application of the factorial design of experiments and response surface methodology to optimize biodiesel production. Ind. Crops Prod 8(1), 29-35.

[197]Wagh, P.B., Begag, R., Pajonk, G.M., Rao, A.V., Haranath, D., 1999. Comparison of some physical properties of silica aerogel monoliths synthesized by different precursors. Mater. Chem. Phys. 57(3), 214-218.

[198]Wan, Y., Shi, Y., Zhao, D., 2008. Supramolecular aggregates as templates: ordered mesoporous polymers and carbons. Chem. Mater. 20(3), 932-945.

[199]Wang, L., Du, W., Liu, D., Li, L., Dai, N., 2006. Lipase-catalyzed biodiesel production from soybean oil deodorizer distillate with absorbent present in tert-butanol system. J. Mol. Catal. B: Enzym. 43(1-4), 29-32

[200]Warabi, Y., Kusdiana, D., Saka, S., 2004. Reactivity of triglycerides and fatty acids of rapeseed oil in supercritical alcohols. Bioresour. Technol. 91(3), 283-287

[201]Watanabe, Y., Shimada, Y., Sugihara, A., Tominaga, Y., 2002 Conversion of degummed soybean oil to biodiesel fuel with immobilized Candida antarctica lipase. J. Mol. Catal. B: Enzym. 17(3-5), 151-155.

[202]Wen, D., Jiang, H., Zhang, K., 2009. Supercritical fluids technology for clean biofuel production. Prog. Nat. Sci. 19(3), 273-284.

[203]Wen, Z., Yu, X., Tu, S.T., Yan, J., Dahlquist, E., 2010. Biodiesel production from waste cooking oil catalyzed by $\mathrm{TiO}_{2}-\mathrm{MgO}$ mixed oxides. Bioresour. Technol. 101(24), 9570-9576.

[204]Williams, J.L., 2001. Monolith structures, materials, properties and uses. Catal. Today. 69(1-4), 3-9.

[205]Xavier Malcata, F., Reyes, H.R., Garcia, H.S., Hill, C.G, Amundson, C.H., 1990. Immobilized lipase reactors for modification of fats and oils-A review. J. Am. Oil Chem. Soc. 67(12), 890-910

[206]Xie, W., Ma, N., 2009. Immobilized lipase on $\mathrm{Fe}_{3} \mathrm{O}_{4}$ nanoparticles as biocatalys for biodiesel production. Energy Fuels. 23(3), 1347-1353.

[207]Xu, Y., Du, W., Liu, D., Zeng, J., 2003. A novel enzymatic route for biodiesel production from renewable oils in a solvent-free medium. Biotechnol. Lett. 25(15), 1239-1241.

[208]Yan, S., Salley, S.O., Simon Ng, K.Y., 2009. Simultaneous transesterification and esterification of unrefined or waste oils over $\mathrm{ZnO}-\mathrm{La}_{2} \mathrm{O}_{3}$ catalysts. Appl. Catal. A 353(2), 203-212.

[209]Yee, K.F., Tan, K.T., Abdullah, A.Z., Lee, K.T., 2009. Life cycle assessment of palm biodiesel: revealing facts and benefits for sustainability. Appl. Energy. 86, S189-S196.

[210] Yin, J.Z., Xiao, M., Song, J.B., 2008a. Biodiesel from soybean oil in supercritical methanol with co-solvent. Energy Convers. Manag. 49(5), 908-912.

[211]Yin, J.Z., Xiao, M., Wang, A.Q., Xiu, Z.L., 2008b. Synthesis of biodiesel from soybean oil by coupling catalysis with subcritical methanol. Energy Convers. Manag. 49(12), 3512-3516. 
[212] Yu, W.H., Fang, M., Tong, D.S., Shao, P., Xu, T.N., Zhou, C.H., 2013. Immobilization of Candida rugosa lipase on hexagonal mesoporous silicas and selective esterification in nonaqueous medium. Biochem. Eng. J. 70, 97-105.

[213] Yucel, Y., 2011. Biodiesel production from pomace oil by using lipase immobilized onto olive pomace. Bioresour. Technol. 102(4), 3977 3980.
[214]Yujun, W., Jian, X., Guangsheng, L., Youyuan, D., 2008. Immobilization of lipase by ultrafiltration and cross-linking onto the polysulfone membrane surface. Bioresour. Technol. 99(7), 22992303.

[215]Zhu, H., Wu, Z., Chen, Y., Zhang, P., Duan, S., Liu, X., Mao, Z., 2006. Preparation of biodiesel catalyzed by solid super base of calcium oxide and its refining process. Chin. J. Catal. 27(5), 391396. 